\title{
The Impact of COVID-19 Restrictions on Childhood Vaccination Uptake: A Rapid Review
}

\author{
Heneghan C, ${ }^{1}$ Brassey J, ${ }^{2}$ Jefferson T. ${ }^{1}$ \\ (Version 1, 21 June 2021) \\ COLLATERAL GLOBAL
}

Affiliations:

1. The University of Oxford

2. Trip Database Ltd https://www.tripdatabase.com

Corresponding author email: carl.heneghan@phc.ox.ac.uk

\begin{abstract}
\section{Background}

Vaccines are highly effective for preventing a range of childhood infections. However, there have been concerns about an alarming decline in vaccinations in 2020 due to the COVID-19 pandemic.
\end{abstract}

\section{Methods}

We performed a rapid review for studies that assessed childhood vaccination uptake during restrictive phases of the COVID-19 pandemic.

\section{Results}

We found 35 published studies that compared changes in the pattern of childhood vaccinations before and during the pandemic. Thirteen were surveys; two mixed-methods surveys and interviews, three modelling studies and 17 retrospective cohort studies with historical controls. We also included ten reports by national or international agencies that had original data on vaccination uptake. Significant global disruptions to vaccine services were reported in Africa, Asia, America (including Latin America and the Caribbean) and Europe. We also found evidence of significant disruption to vaccine uptake for diphtheria tetanus pertussis, BCG, measles and polio. Countries where vaccination rates were already suboptimal had greater drops in uptake and there was evidence of smaller declines in younger children compared to older children. Children born to women who could not read and write were more likely to be incompletely immunized. Various initiatives were used to drive up vaccination rates post restrictions.

\section{Conclusions}

Obstacles to the delivery of vaccination services during the Covid-19 pandemic drove down immunisation rates, especially in disadvantaged people and poorer countries. 
medRxiv preprint doi: https://doi.org/10.1101/2021.06.25.21259371; this version posted June 30, 2021. The copyright holder for this preprint

(which was not certified by peer review) is the author/funder, who has granted medRxiv a license to display the preprint in perpetuity. It is made available under a CC-BY-ND 4.0 International license.

\section{Introduction}

Vaccines have proven to be highly effective at preventing disease and deaths associated with a range of childhood infections. Many childhood diseases that used to be common, including diphtheria, measles, mumps, rubella, pertussis, polio and tetanus, can be prevented by vaccination. The distribution and uptake of vaccines has improved across the globe. In $2019,86 \%$ of infants worldwide received three doses of diphtheria, tetanus, pertussis (DTP3) vaccines, and childhood immunisation is estimated to prevent 2 to 3 million annual deaths from infectious diseases. [1]

Despite their effectiveness, the WHO and UNICEF warned of an 'alarming decline' in vaccinations in 2020 due to the COVID-19 pandemic. Data from the first four months highlighted a substantial drop in the number of children completing three doses of the DTP3 vaccine - the first time in 28 years global reductions were seen. ${ }^{\text {[2] }}$

UNICEF regards protection from vaccinepreventable diseases as a child's fundamental right and states that right now is 'time to vigorously monitor the impact on immunisation and plan for services that reach the most vulnerable once restrictions are lifted. ${ }^{[3]} \mathrm{We}$, therefore, set out to synthesise the published literature on the impact of the COVID-19 pandemic restrictions on vaccination coverage for children.

\section{Methods}

We performed a rapid review using a flexible framework for restricted systematic reviews. ${ }^{[4]}$ For the initial search, we restricted the results to peerreviewed articles using the LitCovid database. LitCovid is a curated literature hub for tracking upto-date scientific information about SARS-CoV-2 (https://www.ncbi.nlm.nih.gov/research/coronaviru s/). It is a comprehensive resource on the subject, providing central access to relevant articles in PubMed. We searched for various terms/phrases associated with childhood vaccinations, e.g., 'vaccines', 'vaccination' or 'immunisation' and 'children' or 'infants'. We screened the title and abstract for inclusion and extracted data into templates on the study identifier, country, the type of vaccination, the study type, the age of the included populations, the primary methods and the main results. We did not formally assess quality as studies were retrospective reviews of records that involved an active lockdown phase and a historical control period, surveys or modelling studies. The quality of included studies was instead assessed using an adapted version of the Oxford Centre for Evidence-Based Medicine Levels of Evidence (https://www.cebm.ox.ac.uk/resources/levels-ofevidence/ocebm-levels-of-evidence)

We also included reports by national or international agencies that included original data on vaccination uptake. We summarised data narratively and reported the outcomes as stated, including quantitative estimates, where feasible and relevant. We presented the data by disruption of services and by diphtheria tetanus pertussis, BCG, measles and polio vaccine uptake. We also extracted up to date numbers from the Global Polio Eradication Initiative (GPEI) database to assess the latest impact of polio vaccination disruptions in Afghanistan and Pakistan, where polio is endemic (https://polioeradication.org/). Our review process, strategy and rationale can be accessed at https://collateralglobal.org/article/what-is-a-rapidreview/.

\section{Results}

Figure 1 reports the Identification of Childhood Vaccination studies via databases. From 389 records identified, we found 35 published studies that compared changes in the pattern of childhood vaccinations before and during the pandemic. 32 studies assessed evidence from 22 countries: Afghanistan, Bangladesh, China, Germany, India, Indonesia, Japan, Kuwait, The Netherlands, Portugal, Rwanda, Scotland, Senegal, Sierra Leone, South Korea, Spain (16 countries, one study each); England, Ethiopia, Italy, Pakistan, Saudi Arabia (five countries, two studies each). For the USA, there were six studies. Three studies reported on multiple countries: two were done in Africa [Masresha 2020 and Abbas K 2020] and one in 
medRxiv preprint doi: https://doi.org/10.1101/2021.06.25.21259371; this version posted June 30, 2021. The copyright holder for this preprint

(which was not certified by peer review) is the author/funder, who has granted medRxiv a license to display the preprint in perpetuity. It is made available under a CC-BY-ND 4.0 International license .

Carl Heneghan, Jon Brassey, and Tom Jefferson

The Impact of COVID-19 Restrictions on Childhood Vaccination Uptake: A Rapid Review

Collateral Global

June 2021
South-East Asia and the Western Pacific (SEAR/WPR) [Harris 2021].

In terms of methods, thirteen studies were surveys; two were mixed-methods surveys and interviews, three studies were models (one provided data on a retrospective cohort), and 17 were retrospective cohort studies.

We also included ten reports by national or international agencies that had original data on vaccination uptake: one each for Blue Cross, the Nuffield Trust, PAHO and Public Health England, two reports for UNICEF (one jointly with PAHO) and four WHO reports. (See TABLE 2)

\section{Disruption to services}

Data collated by the WHO, UNICEF, Gavi, and the Sabin Vaccine Institute show that pandemic restrictions substantially reduced the delivery of immunization services in at least 68 countries affecting over 80 million children under the age of one. [UNICEF 2020] According to the WHO's first pulse interim survey published in August 2020, $16 / 91$ (18\%) of countries reported severe/complete disruption of routine mobile immunization services, and $10 \%$ reported disruption to static routine immunisation services. About half of the countries reported partial disruptions of routine immunisation for both health facilities and mobile services. [WHO first-round survey 2020] On May 15, the pulse survey reported that more than half $(53 \%)$ of the 129 countries with available data had moderate-tosevere disruptions or a total suspension of vaccination services from March to April 2020. [WHO pulse survey 15 May 2020] The WHO's second round national pulse survey from January to March 2021 reported that more than one-third of 135 countries experienced disruptions to immunisation services: routine facility-based disruption occurred in 35 (34\%) countries surveyed and outreach immunisation services occurred in 35 $(39 \%)$ countries. [WHO second-round survey 2021]

\section{Africa}

A review of the administrative routine immunisation data from 15 African countries in 2020 revealed that 13 countries experienced declines in the monthly average number of vaccine doses provided from January to June compared with 2018 and 2019. [Masresha BG 2020]. In Ethiopia, 633 children and their mother/caregiver were interviewed from Jul 22 to Aug 7, 2020. Based on their recall, plus vaccination cards, 350 (57\%) children finished all recommended vaccines. Vaccination coverage during the outbreak was $12.5 \%$ lower than before the outbreak. [Miretu DG 2021]

\section{Asia}

Twenty percent of child immunisation services in Bangladesh were cancelled in April 2020 and 25\% in May. The most significant disruption occurred in remote subdistricts: Hijla (57\%), Agailjhara (25\%) and Mehendiganj (20\%). Improved coverage appeared in the post-disruption months (July to October 2020), with about $99 \%$ of immunisation sessions held. [Rana S 2021] In India, survey data of paediatric healthcare providers from April to June and September 2020 reported a greater than 50\% drop in vaccination services by $83 \%$ of the respondents in June ( $n=424$ respondents) and 33\% in September $(n=141)$. [Shet 2021] In Indonesia, $42 \%(480 / 1137)$ of survey respondents reported disruption of childhood vaccination services in local health facilities and 13\% (193/1137) of respondents explained that their children could not be vaccinated because a healthcare facility temporarily stopped vaccination service. Of all respondents, $312(27 \%)$ delayed vaccinating their children for a compulsory vaccination shot. [Fahriani M 2021] In South Korea, during the outbreak, the vaccination rate in children aged $<35$ months did not decrease significantly, whereas the vaccination rate for children aged 4 to 6 decreased by 1.4 to $1.9 \%$. [Yu 2020] In Japan, COVID-19 resulted in decreases in the vaccination rate for Haemophilus influenza type $b$ in <5-year-olds from approximately $97 \%$ each in 2013 and 2019 to $87 \%$ and $73 \%$ in 2020 for primary and booster doses, respectively. [Kitano 2021] 
medRxiv preprint doi: https://doi.org/10.1101/2021.06.25.21259371; this version posted June 30, 2021. The copyright holder for this preprint (which was not certified by peer review) is the author/funder, who has granted medRxiv a license to display the preprint in perpetuity. It is made available under a CC-BY-ND 4.0 International license.

\section{Middle East}

At the King Saud University Medical City, Riyadh, in Saudi Arabia, electronic health records reported drops in vaccination visits of $50 \%, 72 \%$ and $68 \%$ in March, April, and May 2020 compared with the same months in 2017 to 2019. [Alrabiaah 2020] Furthermore, in the Qassim region of Saudi Arabia, a questionnaire for parents of children under two years of age conducted between 1 May to 30 June 2020 reported that $23 \%$ had a delay of more than one month in the immunisation of their child. The most common reason for delay was fear of COVID-19 infection. [Alsuhaibani M 2020]

\section{Europe}

Weekly survey data from roughly 1,000 participants in Germany reported on 14 April 2020 that 31 of 73 scheduled childhood vaccinations were cancelled within the previous six weeks - $26(84 \%)$ because of the pandemic. Nearly half of the parents $(46 \%)$ indicated that their paediatrician cancelled the appointment. According to the survey, two-thirds of the cancelled vaccination appointments had been caught up, but appointments had not been scheduled for roughly one in five. [Schmid-Küpke 2021] In Lothian, Scotland, fixed-point clinics delivered infants' first vaccinations at various locations accessible by public transport, leading to stable attendance rates. [Jarchow-MacDonald 2021] In Spain, a review of data from Autonomous Communities reported that vaccination coverage in all communities decreased by between $5 \%$ and $60 \%$, depending on the age and type of vaccine. The first dose of meningococcal vaccine $B$ decreased by $68.4 \%$ in the Valencian Community, and Andalusia observed a $39 \%$ decrease in the total doses of this vaccine [Moraga-Llop FA 2020]. In Portugal, survey responses for 19,745 children reported that $21.6 \%$ of planned vaccinations were missed. [Poppe M 2021] Similarly, a survey among Italian families on childhood vaccinations during the lockdown period reported that out of 1474 responders, 34\% skipped vaccine appointments because they were afraid of the SARS-CoV-2 virus, the vaccination provider postponed the appointment, or the service was closed. [Russo R 2021]

\section{USA}

US CDC Data indicated that three million fewer doses of non-influenza vaccines were ordered from 6 January to 19 April 2020, compared with the previous year. [Santoli JM 2020] A decrease was seen in the number of vaccine doses administered in New York City in March and April 2020. In children $<24$ months of age, the largest relative decrease occurred between 5 to 11 April with a $62 \%$ decrease - from 33,261 doses in 2019 to 12,746 doses in 2020. In those aged 2 to 18 years, a $96 \%$ decrease was observed - from 23,631 doses in 2019 to 1,054 doses in 2020. Vaccine administration in children $<24$ months returned to levels comparable with 2019 in May 2020, but in those aged 2 to 18 years, levels had not returned to normal by the end of June. [Langdon-Embry 2020] Blue Cross Blue Shield, which insures 1 in 3 Americans, reported a drop of up to $26 \%$ in MMR, DTP \& polio vaccines between January and Sept 2020. [Blue Cross 2020]

\section{Latin America and the Caribbean}

In Latin America and the Caribbean, difficulties caused by public transport limitations, confinement and physical distance policies, along with fear of COVID, led to a decrease in demand for vaccination services in half of the 38 countries that reported information to the Pan American Health Organization [PAHO] in June 2020. ${ }^{5]}$ [PAHO 2020] Initiatives to increase vaccination rates included institutional drive-through vaccination, mobile vaccination centres, vaccination in homes and strategic locations, follow-up vaccinations using the electronic immunisation registry and emphasis on the importance of maintaining immunisation during a pandemic.

\section{BCG vaccination}

Data from the Rwanda Health Management Information System from March and April 2019 
medRxiv preprint doi: https://doi.org/10.1101/2021.06.25.21259371; this version posted June 30, 2021. The copyright holder for this preprint

(which was not certified by peer review) is the author/funder, who has granted medRxiv a license to display the preprint in perpetuity. It is made available under a CC-BY-ND 4.0 International license .

Carl Heneghan, Jon Brassey, and Tom Jefferson

The Impact of COVID-19 Restrictions on Childhood Vaccination Uptake: A Rapid Review

Collateral Global

June 2021 showed significant reductions in bacille CalmetteGuérin (BCG) compared with 2020. [Wanyana 2021] In Pakistan, there was a 53\% decline in the daily average total vaccinations administered. Provincial electronic immunisation registry data reported about 8,400 children per day missed immunisation during the lockdown phase [Chandir $S$ 2020], with the highest decline seen for BCG immunisation 958/2360). Ethiopia reported that of 1,110 children who started their BCG vaccination, only $798(72 \%)$ completed their immunisations. [Wale 2020] From January to June 2020, Burundi, CAR, Chad, DR Congo, Eritrea, Rwanda and Senegal managed to maintain cumulative numbers of vaccinated children for BCG, compared to the mean of 2018/2019. [Masresha BG 2020]

\section{Diphtheria, Tetanus, Pertussis [DTP]}

The Rwanda data also showed significant reductions in DTP vaccination rates. [Wanyana 2021] Analysis of children receiving the first and third doses of DTP-containing vaccines in Guinea, Nigeria, Ghana, Angola, Gabon, and South Sudan showed drops in monthly vaccination in the second quarter of 2020 for the third dose compared with 2018-19. Burundi, CAR, Chad, DR Congo, Eritrea, Rwanda and Senegal managed to maintain the number of vaccinated children for DPT1 and DPT3. [Masresha BG 2020] Declines were seen in Pakistan, with the likelihood of Penta3 immunisation, which includes the DTP-containing vaccines, reduced by $5 \%$ for each week of delay. Retrospective data from a vaccination unit of a hospital centre in Senegal comparing data for 2018, 2019 and 2020, reported pentavalent vaccine reductions in ten-week-olds. [Sow A 2020]

\section{Measles}

Eleven studies assessed measles vaccination rates: Abbas 2020, Bechini 2020, Bramer 2020, Carias 2021, Masresha 2020, McDonald 2020, Middeldorp 2021, Santoli 2020, Seither 2021, Sow 2020, and Wale 2020.

Two surveys [Bechini 2020 and Wale 2020] reported reductions in vaccine uptake. Nearly a third $(32 \%)$ of 223 paediatricians in Tuscany,
Italy, reported declines in mandatory vaccination, including the measles and rubella vaccine (MMR). Postponements were mainly due to safety fears. [Bechini 2020] A survey in Ethiopia including 1,300 children aged 10 to 23 months reported $798(61 \%)$ had received the measles vaccine. Women who could not read and write were five times more likely to have an incompletely immunised child than those educated with a diploma, degree, and above (Adjusted Odds Ratio $=5.1,95 \% \mathrm{Cl} 2.3-11.1$ ) . [Wale TA 2020]

Retrospective data from US states on local immunisation programs among kindergarten children (age 5-6 years) reported 95\% had two doses of measles, mumps, and rubella vaccine in the 2019/20 school year. COVID disruptions were expected to reduce vaccination coverage in the 2020/21 school year. [Seither R 2021] Data from the Michigan Care Improvement Registry in the US reported that disruptions impacted coverage. For 16-month-olds, measles vaccination coverage decreased from $76.1 \%$ in May 2019 to $70.9 \%$ in May 2020. [Bramer CA 2020] Data from the US CDC reported significant reductions in measles vaccines over 15 weeks. The greatest reduction in orders was reported in the week beginning 13 April, with a cumulative decrease of approximately 400,000 measles doses compared to 2019. Smaller declines were seen in children aged $\leq 24$ months than in older children. [Santoli JM 2020]

A review of routine immunisation data from 15 African countries showed that thirteen saw drops in the monthly average vaccine doses provided. Nine countries had lower monthly first dose measles vaccinations in the second quarter of 2020 compared to the first quarter. Those countries with more inadequate coverage before COVID-19 reported more significant drops in the number vaccinated after the pandemic was declared. [Masresha BG 2020] A retrospective study in a hospital vaccination unit in Senegal comparing measles vaccinations, amongst others, reported significant reductions in coverage. [Sow 2020] On 15 May 2020, as part of the pulse survey, the WHO reported that measles campaigns were suspended in 27 countries. [WHO pulse survey 15 May report 2020]

Electronic health records of children $<1$ year-old in England reported measles-mumps- 
medRxiv preprint doi: https://doi.org/10.1101/2021.06.25.21259371; this version posted June 30, 2021. The copyright holder for this preprint

(which was not certified by peer review) is the author/funder, who has granted medRxiv a license to display the preprint in perpetuity. It is made available under a CC-BY-ND 4.0 International license .

rubella vaccination was $20 \%$ lower in the first three weeks of restrictions than the same period in 2019, before improving in mid-April. [McDonald 2020] The Nuffield Trust reported the number of vaccinations decreased in the week beginning 23 March 2020 (week 13) when lockdown measures began. [Nuffield Trust 2021] Vaccination numbers then increased from week 16 and remained relatively stable at pre-pandemic levels. Public Health England [Public Health England 2021] reported that vaccine coverage for MMR1 between September and December 2020 was lower than 2019 estimates and that coverage was already below the WHO target of $95 \%$ in 2019. [5] In the Netherlands, the first MMR vaccination from March to September 2020 dropped by between 6 and 14\% compared with the previous year. After catch-up vaccinations, a difference in the first MMR vaccination of $-1 \%$ to $-2 \%$ remained. [Middeldorp $M$ 2021]

There were two modelling studies. Abbas $\mathrm{K}$ et al. 2020 modelled a high-impact scenario and a low-impact scenario in Africa to approximate child deaths relating to measles that immunisation coverage reductions could cause during COVID-19 outbreaks. Carias C et al. 2021 modelled projected US measles vaccination coverage for one-yearolds in 2020 for different durations of stay-at-home orders.

\section{Polio}

A Review of the Global Polio Eradication Initiative (GPEI) reported a halt to polio vaccination until the second half of 2020. GPEI comprises six organisations: the WHO, the US CDC, UNICEF, Rotary International, the Bill \& Melinda Gates Foundation, and the Global Alliance for Vaccines and Immunisations. Data from Afghanistan reported 21 confirmed polio cases in 2018, 29 in 2019, and, in 2020, 34 confirmed cases were reported as of August 1, 2020. [Ahmadi 2020]

We reviewed the latest Afghanistan data from GPEI (https://polioeradication.org/). As of 16 June, one case of wild poliovirus type 1 (WPV1) has been reported for 2021 and a total of 56 cases in 2020. ${ }^{[6]}$ The latest status for Afghanistan suggests that the country remains affected by WPV1 and circulating vaccine-derived poliovirus type 2 (cVDPV2). In March 2021, 6.6 million children were vaccinated against polio during the National Immunisation Days. ${ }^{[7]}$ There were forty cases of circulating cVDPV2 reported in 2021 and 308 cases in 2020.

An overview of the impact of COVID-19 on polio vaccination in Pakistan reported that vaccination campaigns in Pakistan were suspended in April 2020. Due to COVID-19-related disruptions to services, 40 million children missed polio vaccinations. [Din M 2020]. In Sindh, Pakistan, one in every two children in the province missed their routine vaccinations during the lockdown period. [Chandir S 2020]

We similarly reviewed the latest data on the GPEI from Pakistan. In 2020, through September, 73 cases of WPV1 were reported in Pakistan and 62 cases of cVDPV2. Cases in Pakistan dropped to eight in 2017, 12 in 2018, and then increased to 147 in 2019. [Chandir S 2020] The latest data from Pakistan as of June 16 reports one case of WPV1 in 2021 and 84 cases in 2020. The number of cVDPV2 cases so far in 2021 is eight; in 2020, there were 135 cases. In March 2021, a national Immunisation campaign ran from 29 March to 2 April 2021, with 40.1 million children vaccinated. [8]

Data from the Rwanda Health Management Information System from March and April 2019 compared to 2020 showed significant reductions in polio 1 and 2 vaccinations. [Wanyana 2021] In a hospital centre in Senegal, polio vaccination was reduced from March to August 2020. [Sow A 2020] Data from Sierra Leone on five common vaccinated diseases from Mar 1, 2020, to Apr 26, 2020, compared with 2019, reported decreases in vaccination ranging from 50 to $85 \%$ depending on the individual vaccine analysed, including the OPV1 vaccine. [Buonsenso D 2021]

In April 2020, The WHO reported that Niger had an outbreak of vaccine-derived poliovirus that affected two children-having suspended the vaccination campaign due to the pandemic. Niger's last wild polio case was in 2012 [9]. Niger joins 15 countries experiencing vaccinederived poliovirus outbreaks in Africa. No wild poliovirus has been detected in Africa since 2016. Niger joins the list of countries experiencing vaccine-derived poliovirus outbreaks in Africa. The 
medRxiv preprint doi: https://doi.org/10.1101/2021.06.25.21259371; this version posted June 30, 2021. The copyright holder for this preprint (which was not certified by peer review) is the author/funder, who has granted medRxiv a license to display the preprint in perpetuity. It is made available under a CC-BY-ND 4.0 International license.

other countries are Angola, Benin, Burkina Faso, Cameroon, Central African Republic, Chad, Côte d'Ivoire, the Democratic Republic of the Congo, Ethiopia, Ghana, Mali, Nigeria, Togo and Zambia.

\section{Discussion}

The evidence in this review comes from a wide range of conditions and countries that highlight significant disruptions to childhood vaccine services. We found reductions in diphtheria tetanus pertussis, BCG, measles and polio vaccine uptake, as well as a range of other vaccines regularly given to children. Reductions in many settings were reversed once restrictions were lifted. However, not all settings reported a return to complete normality. Smaller declines were seen in younger children than older children. In addition, children born to women who could not read and write were more likely to be incompletely immunised. Barriers to access and maintaining public transport infrastructure impacted uptake of childhood vaccinations as well.

The true impact of COVID-19 disruptions on childhood vaccination services is yet to be determined. Two years after reductions in measles vaccination during the Ebola outbreak in Guinea, the incidence of measles increased from 2.7 per million in 2015 to 11.5 per million in 2016 and 52.5 per million in 2017 , of which $65 \%$ of cases were confirmed in those aged $<5$ years. ${ }^{[10]}$ Worldwide measles deaths climbed by 50\% from 2016 to 2019 , with over 200,000 lives lost in 2019. [11]

Low levels of polio vaccination and a lack of immunity can leave countries at risk of polio returning. Indonesia, Mozambique, Myanmar, Papua New Guinea, and the Philippines are currently considered key-at-risk countries by GPEI, Afghanistan, and Pakistan affected by ongoing endemic WPV1 and cVDPV2. [11] There is a concerted effort underway to eradicate polio. The GPEI reports fewer cases in 2021 compared to the same period last year. This is promising, despite the lockdowns; however, the potential for underreporting exists due to the pandemic. The effects of Polio can be devastating: in 1996, wild poliovirus paralysed more than 75,000 children in Africa. [12] Therefore, maintaining sustained vaccination levels and disease surveillance remains a priority for at-risk countries. Furthermore, several barriers were reported to vaccination, including a lack of clarity around whether vaccination services were operating, as usual, difficulties in organising vaccination appointments, and fears around contracting COVID-19. [Bell S 2020]

\section{Limitations}

We did not formally assess the quality of the included studies. However, clinical audit and service evaluation remain valuable for analysing and targeting improvements in healthcare. Publication bias will favour studies that highlight disruptions and account for excess reporting of decreases in vaccination levels. However, alongside those studies, reviews by international bodies highlight consistent drops in vaccination uptakes during the restrictive phases of the pandemic. Studies that report no reductions in vaccination are essential; they highlight strategies that can overcome disruptions during restrictions and - crucially - after they have been lifted. Reports of vaccine coverage may not be $100 \%$ accurate, particularly during periods of upheaval such as in a pandemic.

\section{Conclusions}

COVID-19 pandemic measures caused significant disruption to childhood vaccination services and uptake. In future pandemics, and for the remainder of the current one, policymakers must ensure access to vaccination services and provide catchup programs to maintain high levels of immunisation, especially in those most vulnerable to childhood diseases in order to avoid further inequalities.

\section{Funding}

This review received funding from Collateral Global. In addition, $\mathrm{CH}$ receives funding support from the NIHR SPCR. 
medRxiv preprint doi: https://doi.org/10.1101/2021.06.25.21259371; this version posted June 30, 2021. The copyright holder for this preprint

(which was not certified by peer review) is the author/funder, who has granted medRxiv a license to display the preprint in perpetuity. It is made available under a CC-BY-ND 4.0 International license .

\section{Competing Interest Statement}

TJ was in receipt of a Cochrane Methods Innovations Fund grant to develop guidance on the use of regulatory data in Cochrane reviews (2015 to 2018). From 2014 to 2016 , he was a member of three advisory boards for Boehringer Ingelheim. TJ is occasionally interviewed by market research companies about phase I or II pharmaceutical products for which he receives fees (current). TJ was a member of three advisory boards for Boehringer Ingelheim (2014 to 16). TJ was a member of an independent data monitoring committee for a Sanofi Pasteur clinical trial on an influenza vaccine (2015 to 2017). TJ is a relator in a False Claims Act lawsuit on behalf of the United States that involves sales of Tamiflu for pandemic stockpiling. If resolved in the United States favour, he would be entitled to a percentage of the recovery. TJ is coholder of a Laura and John Arnold Foundation grant for the development of a RIAT support centre (2017 to 2020) and Jean Monnet Network Grant, 2017 to 2020 for The Jean Monnet Health Law and Policy Network. TJ is an unpaid collaborator to the project Beyond Transparency in Pharmaceutical Research and Regulation led by Dalhousie University and funded by the Canadian Institutes of Health Research (2018 to 2022). TJ consulted for Illumina LLC on next-generation gene sequencing (2019 to 2020). TJ was the consultant scientific coordinator for the HTA Medical Technology programme of the Agenzia per i Servizi Sanitari Nazionali (AGENAS) of the Italian $\mathrm{MoH}$ (2007 to 2019). TJ is Director Medical Affairs for BC Solutions, a market access company for medical devices in Europe. TJ was funded by NIHR UK and the World Health Organization (WHO) to update Cochrane review A122, Physical Interventions to interrupt the spread of respiratory viruses. TJ is funded by Oxford University to carry out a living review on the transmission epidemiology of COVID 19. Since 2020, TJ receives fees for articles published by The Spectator and other media outlets. TJ is part of a review group carrying out a Living rapid literature review on the modes of transmission of SARS CoV 2 (WHO Registration $2020 / 1077093$ 0). He is a member of the WHO COVID 19 Infection Prevention and Control
Research Working Group, for which he receives no funds. TJ is funded to co-author rapid reviews on the impact of Covid restrictions by the Collateral Global Organisation.

CJH holds grant funding from the NIHR, the NIHR School of Primary Care Research, the NIHR BRC Oxford and the World Health Organization for a series of Living rapid review on the modes of transmission of SARs-CoV-2 reference WHO registration No2020/1077093. He has received financial remuneration from an asbestos case and given legal advice on mesh and hormone pregnancy tests cases. He has received expenses and fees for his media work, including occasional payments from BBC Radio 4 Inside Health and The Spectator. He receives expenses for teaching EBM and is also paid for his GP work in NHS out of hours (contract Oxford Health NHS Foundation Trust). He has also received income from the publication of a series of toolkit books and appraising treatment recommendations in non-NHS settings. He is the Director of CEBM and is an NIHR Senior Investigator. He is co-director of the Global Centre for healthcare and Urbanisation based at Kellogg College at Oxford, and he is a scientific advisor to Collateral Global.

$\mathrm{JB}$ is a major shareholder in the Trip Database search engine (www.tripdatabase.com) and an employee. In relation to this work, Trip has worked with many organisations over the years; none have any links with this work. Their main current projects are with AXA and Collateral Global.

\section{Acknowledgements}

The authors would like to thank Martin Kulldorff and AJ Kay for comments on the draft.

\section{Ethics Committee Approval}

No approval was necessary.

\section{Data Availability}

All data included in the review is provided in the tables and text. 
medRxiv preprint doi: https://doi.org/10.1101/2021.06.25.21259371; this version posted June 30, 2021. The copyright holder for this preprint (which was not certified by peer review) is the author/funder, who has granted medRxiv a license to display the preprint in perpetuity. It is made available under a CC-BY-ND 4.0 International license.

Carl Heneghan, Jon Brassey, and Tom Jefferson

The Impact of COVID-19 Restrictions on Childhood Vaccination Uptake: A Rapid Review

Collateral Global June 2021

\section{Appendices}


medRxiv preprint doi: https://doi.org/10.1101/2021.06.25.21259371; this version posted June 30, 2021. The copyright holder for this preprint (which was not certified by peer review) is the author/funder, who has granted medRxiv a license to display the preprint in perpetuity.

It is made available under a CC-BY-ND 4.0 International license.

Carl Heneghan, Jon Brassey, and Tom Jefferson

The Impact of COVID-19 Restrictions on Childhood Vaccination Uptake: A Rapid Review

Collateral Global June 2021

\section{General References}

1. World Health Organization. Vaccines and immunisation https://www.who.int/health-topics/vaccinesand-immunization\#tab=tab 1

2. https://www.who.int/news/item/15-07-2020-who-and-unicef-warn-of-a-decline-in-vaccinations-duringcovid-19

3. https://www.unicef.org/eap/stories/impact-covid-19-routine-vaccinations

4. Plüddemann A, Aronson JK, Onakpoya I, et al Redefining rapid reviews: a flexible framework for restricted systematic reviews. BMJ Evidence-Based Medicine 2018;23:201-203.

https://ebm.bmj.com/content/23/6/201

5.https://assets.publishing.service.gov.uk/government/uploads/system/uploads/attachment data/file/9615 39/hpr0321 chldhd-vc wk4d.pdf

6. Afghanistan. https://polioeradication.org/where-we-work/afghanistan/

7. https://polioeradication.org/news-post/afghanistan-polio-snapshot-march-2021/

8. https://polioeradication.org/where-we-work/pakistan/

9. https://www.afro.who.int/news/niger-reports-new-polio-outbreak

10. Masresha BG, Luce R Jr, Weldegebriel G, Katsande R, Gasasira A, Mihigo R. The impact of a prolonged ebola outbreak on measles elimination activities in Guinea, Liberia and Sierra Leone, 20142015. Pan Afr Med J. 2020;35(Suppl 1):8. Published 2020 Jan 6.

doi:10.11604/pamj.supp.2020.35.1.19059 https://www.ncbi.nlm.nih.gov/pmc/articles/PMC7196330/

11. Worldwide measles deaths climb 50\% from 2016 to 2019 claiming over 207500 lives in 2019.

https://www.who.int/news/item/12-11-2020-worldwide-measles-deaths-climb-50-from-2016-to-2019claiming-over-207-500-lives-in-2019

12. https://polioeradication.org/where-we-work/key-at-risk-countries/ 
medRxiv preprint doi: https://doi.org/10.1101/2021.06.25.21259371; this version posted June 30, 2021. The copyright holder for this preprint (which was not certified by peer review) is the author/funder, who has granted medRxiv a license to display the preprint in perpetuity. It is made available under a CC-BY-ND 4.0 International license .

\section{References to Included Studies, Tables 1 \& 2:}

\section{Primary Studies on Childhood Vaccination Uptake During the COVID-19 Pandemic (TABLE 1)}

- Abbas K 2020 Routine childhood immunisation during the COVID-19 pandemic in Africa: a benefit-risk analysis of health benefits versus excess risk of SARS-CoV-2 infection. Lancet Glob Health. 2020 Oct;8(10):e1264-e1272. 10.1016/S2214-109X(20)30308-9 https://www.thelancet.com/journals/langlo/article/PIIS2214-109X(20)30308-9/fulltext

- Ahmadi A 2020 Polio in Afghanistan: The Current Situation amid COVID-19. Am J Trop Med Hyg. 2020 Oct;103(4):1367-1369 10.4269/ajtmh.20-1010 https://www.ajtmh.org/view/journals/tpmd/103/4/article-p1367.xml

- AlHajri B 2021 Willingness of parents to vaccinate their children against influenza and the novel coronavirus disease-2019. J Pediatr. 2021 Apr;231:298-299 10.1016/j.jpeds.2020.11.059 https://www.jpeds.com/article/S0022-3476(20)31471-2/fulltext\#\%20

- Alrabiaah AA 2020 Effects of the Coronavirus disease 2019 pandemic on routine pediatric immunisation coverage rates at the main University Hospital in Saudi Arabia. Saudi Med J. 2020 Nov;41(11):1197-1203. 10.15537/smj.2020.11.25457 https://smj.org.sa/content/41/11/1197

- Alsuhaibani M 2020 Impact of the COVID-19 Pandemic on Routine Childhood Immunization in Saudi Arabia. Vaccines (Basel). 2020 Oct 3;8(4):581. 10.3390/vaccines8040581 https://www.ncbi.nlm.nih.gov/pmc/articles/PMC7711657/

- Bechini A 2020 Paediatric activities and adherence to vaccinations during the COVID-19 epidemic period in Tuscany, Italy: a survey of paediatricians. J Prev Med Hyg. $2020 \mathrm{Jul}$ 4;61(2):E125-E129. 10.15167/2421-4248/jpmh2020.61.2.1626 https://www.jpmh.org/index.php/jpmh/article/view/1626

- Bell S 2020 Parents' and guardians' views and experiences of accessing routine childhood vaccinations during the coronavirus (COVID-19) pandemic: A mixed methods study in England. PLoS One. 2020 Dec 28;15(12):e0244049. 10.1371/journal.pone.0244049 https://journals.plos.org/plosone/article?id=10.1371/journal.pone.0244049

- Bramer CA 2020 Decline in child vaccination coverage during the COVID-19 pandemic Michigan Care Improvement Registry, May 2016-May 2020. Am J Transplant. 2020 Jul;20(7):1930-1931 10.1111/ajt.16112 https://onlinelibrary.wiley.com/doi/full/10.1111/ajt.16112

- Buonsenso D 2021 Child Healthcare and Immunizations in Sub-Saharan Africa During the COVID-19 Pandemic. Front Pediatr. 2020 Aug 6;8:517. 10.3389/fped.2020.00517 https://www.frontiersin.org/articles/10.3389/fped.2020.00517/full

- Carias C 2021 Potential impact of COVID-19 pandemic on vaccination coverage in children: A case study of measles-containing vaccine administration in the United States (US). Vaccine. 2021 
medRxiv preprint doi: https://doi.org/10.1101/2021.06.25.21259371; this version posted June 30, 2021. The copyright holder for this preprint (which was not certified by peer review) is the author/funder, who has granted medRxiv a license to display the preprint in perpetuity. It is made available under a CC-BY-ND 4.0 International license .

Feb 22;39(8):1201-1204 10.1016/j.vaccine.2020.11.074

https://www.sciencedirect.com/science/article/pii/S0264410X20315577?via\%3Dihub\#!

- Chandir S 2020 Impact of COVID-19 pandemic response on uptake of routine immunisations in Sindh, Pakistan: An analysis of provincial electronic immunisation registry data. Vaccine. 2020 Oct 21;38(45):7146-7155 10.1016/j.vaccine.2020.08.019 https://www.sciencedirect.com/science/article/pii/S0264410X20310501?via\%3Dihub

- Din M 2020 Impact of COVID-19 on polio vaccination in Pakistan: a concise overview. Rev Med Virol. 2020 Nov 11 10.1002/rmv.2190 https://onlinelibrary.wiley.com/doi/10.1002/rmv.2190

- Fahriani M 2021 Disruption of childhood vaccination during the COVID-19 pandemic in Indonesia. Narra J: Vol. 1 No. 1 (2021) 10.52225/narraj.v1i1.7 https://www.narraj.org/main/article/view/7

- Harris RC 2021 Impact of COVID-19 on routine immunisation in South-East Asia and Western Pacific: Disruptions and solutions. Lancet Reg Health West Pac. 2021 May;10:100140.

10.1016/j.lanwpc.2021.100140

https://www.sciencedirect.com/science/article/pii/S2666606521000493

- Hou Z 2021 Influence of the COVID-19 epidemic on prevention and vaccination behaviors among Chinese children and adolescents: results from an online survey. JMIR Public Health Surveill. 2021 May 26;7(5):e26372. 10.2196/26372 https://preprints.jmir.org/preprint/26372/accepted

- Jarchow-MacDonald AA 2021 Keeping childhood immunisation rates stable during the COVID-19 pandemic. Lancet Infect Dis. 2021 Apr;21(4):459-460 10.1016/S1473-3099(20)30991-9 https://www.thelancet.com/journals/laninf/article/PIIS1473-3099(20)30991-9/fulltext

- Kitano T 2021 A model for the incremental burden of invasive Haemophilus influenzae type b due to a decline of childhood vaccination during the COVID-19 outbreak: A dynamic transmission model in Japan. Vaccine. 2021 Jan 8;39(2):343-349 10.1016/j.vaccine.2020.11.053 https://www.sciencedirect.com/science/article/pii/S0264410X20315061?via\%3Dihub\#!

- Langdon-Embry M 2020 Notes from the Field: Rebound in Routine Childhood Vaccine Administration Following Decline During the COVID-19 Pandemic - New York City, March 1June 27, 2020. MMWR Morb Mortal Wkly Rep. 2020 Jul 31;69(30):999-1001.

10.15585/mmwr.mm6930a3

https://www.cdc.gov/mmwr/volumes/69/wr/mm6930a3.htm?s cid=mm6930a3 w

- Masresha BG 2020 The performance of routine immunisation in selected African countries during the first six months of the COVID-19 pandemic. Pan Afr Med J. 2020 Sep 18;37(Suppl 1):12.

10.11604/pamj.supp.2020.37.12.26107 https://www.ncbi.nlm.nih.gov/pmc/articles/PMC7733346/

- McDonald HI 2020 Early impact of the coronavirus disease (COVID-19) pandemic and physical distancing measures on routine childhood vaccinations in England, January to April 2020. Euro Surveill. 2020 May 14; 25(19): 2000848 10.2807/1560-7917.ES.2020.25.19.2000848 https://www.ncbi.nlm.nih.gov/labs/pmc/articles/PMC7238742/ 
medRxiv preprint doi: https://doi.org/10.1101/2021.06.25.21259371; this version posted June 30, 2021. The copyright holder for this preprint (which was not certified by peer review) is the author/funder, who has granted medRxiv a license to display the preprint in perpetuity. It is made available under a CC-BY-ND 4.0 International license.

- Middeldorp M 2021 Short term impact of the COVID-19 pandemic on incidence of vaccine preventable diseases and participation in routine infant vaccinations in the Netherlands in the period March-September 2020. Vaccine. 2021 Feb 12;39(7):1039-1043

10.1016/j.vaccine.2020.12.080 https://www.sciencedirect.com/science/article/pii/S0264410X20316923

- Miretu DG 2021 Impact of COVID-19 pandemic on vaccination coverage among children aged 15 to 23 months at Dessie town, Northeast Ethiopia, 2020. Hum Vaccin Immunother. 2021 Mar 15;19 10.1080/21645515.2021.1883387 https://www.tandfonline.com/doi/abs/10.1080/21645515.2021.1883387?journalCode=khvi20

- Moraga-Llop FA 2020 Recovering lost vaccine coverage due to COVID-19 pandemic. Vacunas. Jul-Dec 2020;21(2):129-135 10.1016/j.vacun.2020.07.001 https://www.sciencedirect.com/science/article/abs/pii/S1576988720300352?via\%3Dihub\#!

- Poppe M 2021 The Impact of the COVID-19 Pandemic on Children's Health in Portugal: The Parental Perspective. Acta Med Port. 2021 Mar 26 10.20344/amp.14805 https://actamedicaportuguesa.com/revista/index.php/amp/article/view/14805

- Rana S 2021 Post-disruption catch-up of child immunisation and healthcare services in Bangladesh. Lancet Infect Dis. 2021 Mar 30;S1473-3099(21)00148-1 10.1016/S14733099(21)00148-1 https://www.thelancet.com/journals/laninf/article/PIIS1473-3099(21)00148$1 /$ fulltext\#\%20

- Russo R 2021 Pediatric routine vaccinations in the COVID 19 lockdown period: the survey of the Italian Pediatric Society. Ital J Pediatr. 2021 Mar 24;47(1):72 10.1186/s13052-021-01023-6 https://ijponline.biomedcentral.com/articles/10.1186/s13052-021-01023-6

- Santoli JM 2020 Effects of the COVID-19 Pandemic on Routine Pediatric Vaccine Ordering and Administration — United States, 2020. MMWR Morb Mortal Wkly Rep. 2020 May 15;69(19):591593 10.15585/mmwr.mm6919e2 https://www.cdc.gov/mmwr/volumes/69/wr/mm6919e2.htm

- Schmid-Küpke NK 2021 Cancelled routine vaccination appointments due to COVID-19 pandemic in Germany. Vaccine X. 2021 Aug;8:100094 10.1016/j.jvacx.2021.100094 https://www.sciencedirect.com/science/article/pii/S2590136221000115?via\%3Dihub\#!

- Seither R 2021 Vaccination Coverage with Selected Vaccines and Exemption Rates Among Children in Kindergarten - United States, 2019-20 School Year. MMWR Morb Mortal Wkly Rep. 2021 Jan 22;70(3):75-82 10.15585/mmwr.mm7003a2 https://www.cdc.gov/mmwr/volumes/70/wr/mm7003a2.htm?s cid=mm7003a2 w

- Shet A 2021 COVID-19-related disruptions to routine vaccination services in India: perspectives from pediatricians. medRxiv 2021.01.25.21250040 10.1101/2021.01.25.21250040 https://www.medrxiv.org/content/10.1101/2021.01.25.21250040v1 
medRxiv preprint doi: https://doi.org/10.1101/2021.06.25.21259371; this version posted June 30, 2021. The copyright holder for this preprint (which was not certified by peer review) is the author/funder, who has granted medRxiv a license to display the preprint in perpetuity.

It is made available under a CC-BY-ND 4.0 International license .

- Sow A 2020 Effect of COVID-19 on routine immunisation schedule in Senegalese hospitals. Pan Afr Med J. 2020 Dec 21;37:364 10.11604/pamj.2020.37.364.25805 https://www.panafrican-medjournal.com/content/article/37/364/full/

- Vogt TM 2020 Provision of Pediatric Immunization Services During the COVID-19 Pandemic: an Assessment of Capacity Among Pediatric Immunization Providers Participating in the Vaccines for Children Program — United States, May 2020.MMWR Morb Mortal Wkly Rep. 2020 Jul 10;69(27):859-863 10.15585/mmwr.mm6927a2 https://www.cdc.gov/mmwr/volumes/69/wr/mm6927a2.htm?s cid=mm6927a2 w

- Wale TA 2020 Immunisation Status and Challenges During COVID-19 and Associated Factors Among Children Aged 10-23 Months in South Region, Ethiopia 2020. Pediatric Health Med Ther. 2021 Mar 8;12:101-109 10.2147/PHMT.S294739 https://www.dovepress.com/immunizationstatus-and-challenges-during-covid-19-and-associated-fact-peer-reviewed-fulltext-article-PHMT

- Wanyana D 2021 Rapid assessment on the utilisation of maternal and child health services during COVID-19 in Rwanda. Public Health Action. 2021 Mar 21;11(1):12-21

10.5588/pha.20.0057

https://www.ingentaconnect.com/content/iuatld/pha/2021/00000011/00000001/art00004;jsessioni d=26dk6ltc5q1ur. $x$-ic-live-03

- Yu JH 2021 Sustained Vaccination Coverage during the Coronavirus Disease 2019 Epidemic in the Republic of Korea. Vaccines (Basel). 2020 Dec 22;9(1):2 10.3390/vaccines9010002 https://www.mdpi.com/2076-393X/9/1/2

\section{Reports by National and International Agencies on Childhood Vaccination Uptake During the COVID-19 Pandemic (TABLE 2)}

- Blue Cross 2020. Blue Cross Blue Shield. Missing vaccinations during COVID-19 puts our children and communities at risk. https://www.bcbs.com/the-health-ofamerica/infographics/missing-vaccinations-during-covid-19-puts-our-children-and-communitiesat-risk

- Nuffield Trust 2021. Vaccination coverage for children and mothers. https://www.nuffieldtrust.org.uk/resource/vaccination-coverage-for-children-and-mothers-1

- Public Health England 2021. Impact of COVID-19 on childhood vaccination counts to week 4 in 2021, and vaccine coverage to December 2020 in England: interim analyses. 
medRxiv preprint doi: https://doi.org/10.1101/2021.06.25.21259371; this version posted June 30, 2021. The copyright holder for this preprint (which was not certified by peer review) is the author/funder, who has granted medRxiv a license to display the preprint in perpetuity.

It is made available under a CC-BY-ND 4.0 International license.

Carl Heneghan, Jon Brassey, and Tom Jefferson

The Impact of COVID-19 Restrictions on Childhood Vaccination Uptake: A Rapid Review

Collateral Global June 2021

https://assets.publishing.service.gov.uk/government/uploads/system/uploads/attachment data/file 1961539/hpr0321 chldhd-vc wk4d.pdf

- UNICEF 2020. Challenges posed by the COVID-19 pandemic in the health of women, children, and adolescents in Latin America and the Caribbean.

https://www.unicef.org/lac/media/16376/file/undp-rblac-CD19-PDS-Number19-UNICEF-SaludEN.pdf

- PAHO* 2020. Summary of the Status of National Immunization Programs during the COVID-19 Pandemic, July 2020. https://iris.paho.org/handle/10665.2/52544

- UNICEF 2020. Immunisation coverage. Are we losing ground? https://data.unicef.org/resources/immunization-coverage-are-we-losing-ground/

- WHO pulse interim survey 2020. Pulse survey on continuity of essential health services during the COVID-19 pandemic: interim report, 27 August 2020.

https://www.who.int/publications/i/item/WHO-2019-nCoV-EHS continuity-survey-2020.1

- WHO pulse second round survey 2021. Second round of the national pulse survey on continuity of essential health services during the COVID-19 pandemic.

https://www.who.int/publications/i/item/WHO-2019-nCoV-EHS-continuity-survey-2021.1

- WHO pulse survey 15 May report 2020. At least 80 million children under one at risk of diseases such as diphtheria, measles and polio as COVID-19 disrupts routine vaccination efforts, warn Gavi, WHO and UNICEF. https://www.who.int/news/item/22-05-2020-at-least-80-million-childrenunder-one-at-risk-of-diseases-such-as-diphtheria-measles-and-polio-as-covid-19-disrupts-routinevaccination-efforts-warn-gavi-who-and-unicef

- WHO Niger 2020. Niger reports new polio outbreak. https://www.afro.who.int/news/niger-reportsnew-polio-outbreak 
medRxiv preprint doi: https://doi.org/10.1101/2021.06.25.21259371; this version posted June 30, 2021. The copyright holder for this preprint (which was not certified by peer review) is the author/funder, who has granted medRxiv a license to display the preprint in perpetuity. It is made available under a CC-BY-ND 4.0 International license .

Carl Heneghan, Jon Brassey, and Tom Jefferson

The Impact of COVID-19 Restrictions on Childhood Vaccination Uptake: A Rapid Review

Collateral Global June 2021

\section{TABLE 1: Primary Studies on Childhood Vaccination Uptake During the COVID-19 Pandemic}

\begin{tabular}{|c|c|c|c|c|c|c|}
\hline Author & Country & $\begin{array}{l}\text { Type of } \\
\text { Vaccine }\end{array}$ & $\begin{array}{l}\text { Type of } \\
\text { Evidence }\end{array}$ & Methods & Population & Impact \\
\hline $\begin{array}{l}\text { Abbas K } \\
2020\end{array}$ & Africa & General & Modelling & $\begin{array}{l}\text { Modelling of a high-impact } \\
\text { scenario and a low-impact } \\
\text { scenario to approximate child } \\
\text { deaths that could be caused } \\
\text { by immunisation coverage } \\
\text { reductions during COVID-19 } \\
\text { outbreaks. }\end{array}$ & $<5$ years & $\begin{array}{l}\text { High-impact scenario: for } \\
\text { every one excess COVID-19 } \\
\text { death related to SARS-CoV- } \\
2 \text { acquired during routine } \\
\text { vaccination visits, } 84 \text { ( } 95 \% \\
\text { UI 14-267) deaths in } \\
\text { children could be prevented } \\
\text { by sustaining routine } \\
\text { immunisation in Africa. In } \\
\text { the low-impact scenario that } \\
\text { approximates the health } \\
\text { benefits to only the child } \\
\text { deaths averted from } \\
\text { measles the benefit-risk } \\
\text { ratio to the households of } \\
\text { vaccinated children is } 3 \\
\text { ( } 0 \cdot 5-10) \text {; if the risk to only } \\
\text { the vaccinated children is } \\
\text { considered, the benefit-risk } \\
\text { ratio is } 3000(182-21000) \text {. }\end{array}$ \\
\hline $\begin{array}{l}\text { Alrabiaah } \\
\text { AA } 2020\end{array}$ & $\begin{array}{l}\text { Saudi } \\
\text { Arabia }\end{array}$ & General & $\begin{array}{l}\text { Retrospective } \\
\text { cohort }\end{array}$ & $\begin{array}{l}\text { At the King Saud University } \\
\text { Medical City, Riyadh, Saudi } \\
\text { Arabia electronic health } \\
\text { records were reviewed for } \\
\text { children at birth and at } 2,4,6 \text {, } \\
9 \text {, and } 12 \text { months during Mar- } \\
\text { May } 2017 \text { - } 2020 \text { (sample } \\
=15,870 \text { children). }\end{array}$ & $0-12$ months & $\begin{array}{l}\text { In March, April, and May } \\
2020 \text { there were respective } \\
\text { drops in vaccination visits of } \\
50 \%, 72 \% \text { and } 68 \% \\
\text { compared with the mean } \\
\text { numbers of vaccination } \\
\text { visits during the same } \\
\text { months from } 2017 \text { to } 2019 \text {. }\end{array}$ \\
\hline $\begin{array}{l}\text { Alsuhaibani } \\
\text { M } 2020\end{array}$ & $\begin{array}{l}\text { Saudi } \\
\text { Arabia }\end{array}$ & General & Survey & $\begin{array}{l}\text { In the Qassim region, Saudi } \\
\text { Arabia a cross-sectional } \\
\text { study using an online self- } \\
\text { administered questionnaire } \\
\text { for parents of children under } \\
\text { two years of age during the } \\
\text { period from } 1 \text { May to } 30 \text { June } \\
2020 \text {. }\end{array}$ & $<2$ years & $\begin{array}{l}\text { Nearly three-quarters } \\
(73.2 \%) \text { of the parents had } \\
\text { appointments scheduled for } \\
\text { their child's vaccination } \\
\text { during the pandemic, and } \\
\text { approximately } 23.4 \% \text { of the } \\
\text { parents reported a delay of } \\
\text { more than one month in the } \\
\text { immunization of their child. } \\
\text { The most common reason } \\
\text { for the delay was the fear of } \\
\text { being infected by COVID-19 } \\
(60.9 \%) \text {. }\end{array}$ \\
\hline $\begin{array}{l}\text { Bechini A } \\
2020\end{array}$ & Italy & General & Survey & $\begin{array}{l}\text { Four hundred members } \\
\text { belonging to the Italian } \\
\text { Federation of Paediatricians } \\
\text { (FIMP) in Tuscany were } \\
\text { invited to answer a semi- } \\
\text { structured online survey. }\end{array}$ & Paediatricians & $\begin{array}{l}\text { Among } 223 \text { respondent } 93 \% \\
\text { (208) guaranteed } \\
\text { vaccination activities; } 66 \\
\text { paediatricians (32\%) } \\
\text { reported a reduction in the } \\
\text { compliance of parents to } \\
\text { mandatory vaccination } \\
\text { (hexavalent and MMRV } \\
\text { vaccines), and } 88 \\
\text { paediatricians }(42 \%) \text { to non- } \\
\text { mandatory vaccinations. }\end{array}$ \\
\hline Bell S 2020 & England & General & $\begin{array}{l}\text { Survey \& } \\
\text { semi- } \\
\text { structured } \\
\text { interviews }\end{array}$ & $\begin{array}{l}1252 \text { parents and guardians } \\
\text { in England with a child aged } \\
\text { under } 18 \text { months completed } \\
\text { the survey and } 19 \\
\text { respondents took part in } \\
\text { follow-up interviews. }\end{array}$ & $\leq 18$ months & $\begin{array}{l}86 \% \text { of survey respondents } \\
\text { considered it important for } \\
\text { their children to receive } \\
\text { routine vaccinations on } \\
\text { schedule. Several barriers } \\
\text { to vaccination were }\end{array}$ \\
\hline
\end{tabular}


medRxiv preprint doi: https://doi.org/10.1101/2021.06.25.21259371; this version posted June 30, 2021. The copyright holder for this preprint (which was not certified by peer review) is the author/funder, who has granted medRxiv a license to display the preprint in perpetuity. It is made available under a CC-BY-ND 4.0 International license .

Carl Heneghan, Jon Brassey, and Tom Jefferson

The Impact of COVID-19 Restrictions on Childhood Vaccination Uptake: A Rapid Review

Collateral Global June 2021

\begin{tabular}{|c|c|c|c|c|c|c|}
\hline & & & & & & $\begin{array}{l}\text { identified. These included a } \\
\text { lack of clarity around } \\
\text { whether vaccination } \\
\text { services were operating as } \\
\text { usual; difficulties in } \\
\text { organising vaccination } \\
\text { appointments; and fears } \\
\text { around contracting COVID- } \\
19\end{array}$ \\
\hline $\begin{array}{l}\text { Bramer CA } \\
2020\end{array}$ & USA & General & $\begin{array}{l}\text { Retrospective } \\
\text { cohort }\end{array}$ & $\begin{array}{l}\text { Cohorts for } 2016-2019 \\
\text { compared with } 2020 \text { using } \\
\text { data from the Michigan Care } \\
\text { Improvement Registry (the } \\
\text { state's immunization } \\
\text { information system) }\end{array}$ & $\begin{array}{c}1,3,5,7,16 \\
19, \text { and } 24 \\
\text { months }\end{array}$ & $\begin{array}{l}\text { Among children aged } 5 \\
\text { months, recommended } \\
\text { vaccines declined from an } \\
\text { average of } 67 \% \text { in } 2016- \\
2019 \text { to } 50 \% \text { (absolute } \\
\text { reduction } 17.6 \% \text { ) in May } \\
2020 \text {. For } 16 \text {-mth olds, } \\
\text { measles vaccination } \\
\text { coverage decreased from } \\
76 \% \text { in } 2019 \text { to } 71 \% \text { in } \\
2020 \text {. Non-Influenza vaccine } \\
\text { doses administered for } \\
\text { children aged } \leq 24 \text { months } \\
\text { decreased } 15.5 \% \text { during } \\
\text { Jan-Apr } 2020 \text {. }\end{array}$ \\
\hline $\begin{array}{l}\text { Buonsenso } \\
\text { D } 2021\end{array}$ & $\begin{array}{l}\text { Sierra } \\
\text { Leone }\end{array}$ & General & $\begin{array}{l}\text { Retrospective } \\
\text { cohort }\end{array}$ & $\begin{array}{l}\text { Review at the Kent } \\
\text { Community Health Post, } \\
\text { Sierra Leone (estimated } \\
\text { popn. } 5,000 \text { ) from Mar } 1 \text { to } \\
\text { Apr } 26,2020 \text { and compared } \\
\text { with } 2019 \text {. }\end{array}$ & $<5$ years & $\begin{array}{l}\text { A lower number of children } \\
\text { received vaccination in } 2020 \\
\text { compared with } 2019 \text {, } \\
\text { ranging from } 50 \text { to } 85 \% \\
\text { depending on the individual } \\
\text { vaccine analysed, including } \\
\text { BCG and OPV1. Second } \\
\text { measles vaccinations } \\
\text { dropped by } 84 \% \text { from } 49 \\
\text { children in } 2019 \text { to } 8 \text { in } \\
2020 \text {. }\end{array}$ \\
\hline $\begin{array}{l}\text { Chandir S } \\
2020\end{array}$ & Pakistan & General & $\begin{array}{l}\text { Retrospective } \\
\text { cohort }\end{array}$ & $\begin{array}{l}\text { Individual immunization } \\
\text { records from real-time } \\
\text { Electronic Immunization } \\
\text { Registry from Sep } 23,2019, \\
\text { to Jul } 11,2020, \text { comparing } \\
\text { baseline ( } 6 \text { months before } \\
\text { lockdown and lockdown } \\
\text { period. }\end{array}$ & Children & $\begin{array}{l}\text { A } 53 \% \text { decline in the daily } \\
\text { average number of } \\
\text { vaccinations administered } \\
\text { during lockdown compared } \\
\text { to baseline. The highest } \\
\text { decline was for BCG (40.6\% } \\
\text { (958/2360). Around } 8438 \\
\text { children/day were missing } \\
\text { immunization during the } \\
\text { lockdown. Enrollments } \\
\text { declined furthest in rural } \\
\text { districts, urban sub-districts } \\
\text { with large slums, and polio- } \\
\text { endemic super high-risk } \\
\text { sub-districts. Pentavalent-3 } \\
\text { (Penta-3) immunization } \\
\text { rates were higher in infants } \\
\text { born in hospitals (RR: } 1.09 \text {; } \\
\text { 95\% Cl: } 1.04-1.15) \text { and } \\
\text { those mothers with higher } \\
\text { education (RR: } 1.19-1.50 ; \\
95 \% \text { Cl: } 1.13-1.65) \text {. }\end{array}$ \\
\hline $\begin{array}{l}\text { Fahriani M } \\
2021\end{array}$ & Indonesia & General & Survey & $\begin{array}{l}\text { A nationwide, online, cross- } \\
\text { sectional study. A set of } \\
\text { questionnaires assessed the } \\
\text { disruption of childhood } \\
\text { vaccinations and possible } \\
\text { explanatory variables. }\end{array}$ & Children & $\begin{array}{l}\text { Disruption of childhood } \\
\text { vaccination service was } \\
\text { reported in } 42 \% \text { ( } 480 / 1137) \\
\text { of respondents and } 13.3 \% \\
\text { (193/1137) explained that } \\
\text { their children could not be } \\
\text { vaccinated because a } \\
\text { facility temporarily stopped } \\
\text { the vaccination service. Of }\end{array}$ \\
\hline
\end{tabular}


medRxiv preprint doi: https://doi.org/10.1101/2021.06.25.21259371; this version posted June 30, 2021. The copyright holder for this preprint (which was not certified by peer review) is the author/funder, who has granted medRxiv a license to display the preprint in perpetuity. It is made available under a CC-BY-ND 4.0 International license .

Carl Heneghan, Jon Brassey, and Tom Jefferson

The Impact of COVID-19 Restrictions on Childhood Vaccination Uptake: A Rapid Review

Collateral Global June 2021

\begin{tabular}{|c|c|c|c|c|c|c|}
\hline & & & & & & $\begin{array}{l}\text { all respondents, } 312 \\
(27.4 \%) \text { delayed vaccinating } \\
\text { their children for a } \\
\text { compulsory vaccination } \\
\text { shot. }\end{array}$ \\
\hline $\begin{array}{l}\text { Harris RC } \\
2021\end{array}$ & $\begin{array}{l}\text { South-East } \\
\text { Asia and } \\
\text { Western } \\
\text { Pacific }\end{array}$ & General & Survey & $\begin{array}{l}\text { Sanofi Pasteur teams from } 19 \\
\text { countries in SEAR/WPR } \\
\text { completed a structured } \\
\text { questionnaire reporting on } \\
\text { COVID-19 disruptions for 13- } \\
19 \text { routinely delivered } \\
\text { antigens per country, based } \\
\text { on sales data, government } \\
\text { reports, and regular physician } \\
\text { interactions. }\end{array}$ & Children & $\begin{array}{l}95 \%(18 / 19) \text { of countries } \\
\text { reported vaccination } \\
\text { disruption. Infancy and } \\
\text { school-entry age } \\
\text { vaccinations were most } \\
\text { impacted. Vaccination rates } \\
\text { had not recovered for } 39 \% \\
\text { of impacted antigens by } 1 \\
\text { June } 2020 \text {. Fear of infection, } \\
\text { movement/travel } \\
\text { restrictions, and limited } \\
\text { healthcare access were the } \\
\text { highest-ranked reasons for } \\
\text { disruption. The highest- } \\
\text { scoring solutions were } \\
\text { separating vaccination } \\
\text { groups from unwell patients, } \\
\text { non-traditional vaccination } \\
\text { venues, virtual engagement, } \\
\text { and social media } \\
\text { campaigns. Many of these } \\
\text { solutions were under- } \\
\text { utilised. }\end{array}$ \\
\hline $\begin{array}{l}\text { Hou Z } \\
2021\end{array}$ & China & General & Survey & $\begin{array}{l}\text { An online survey in mid- } \\
\text { March } 2020 \text { using } \\
\text { proportional quota sampling } \\
\text { in Wuhan (the epicentre) and } \\
\text { Shanghai (a non-epicentre) }\end{array}$ & $3-17$ years & $\begin{array}{l}\text { Parent-reported vaccination } \\
\text { behaviours showed } 75 \% \\
\text { delayed scheduled vaccines } \\
\text { and } 81 \% \text { planned to have } \\
\text { their children get the } \\
\text { influenza vaccine after the } \\
\text { epidemic. }\end{array}$ \\
\hline $\begin{array}{l}\text { Jarchow- } \\
\text { MacDonald } \\
2021\end{array}$ & Scotland & General & $\begin{array}{l}\text { Retrospective } \\
\text { cohort }\end{array}$ & $\begin{array}{l}\text { Analysis In Lothian, Scotland } \\
\text { of first vaccinations delivered } \\
\text { by fixed-point clinics }\end{array}$ & Children & $\begin{array}{l}\text { Attendance rates were } \\
\text { stable. }\end{array}$ \\
\hline $\begin{array}{l}\text { Langdon- } \\
\text { Embry } \\
2020\end{array}$ & USA & General & $\begin{array}{l}\text { Retrospective } \\
\text { cohort }\end{array}$ & $\begin{array}{l}\text { Routine childhood } \\
\text { vaccination was monitored by } \\
\text { the NYC Department of } \\
\text { Health and Mental Hygiene } \\
\text { (DOHMH) using the Citywide } \\
\text { Immunization Registry (CIR), }{ }^{*} \\
\text { a population-based } \\
\text { immunization information } \\
\text { system with high data quality } \\
\text { and provider participation }\end{array}$ & $\begin{array}{l}<24 \text { months } \\
\& 2-18 \text { years }\end{array}$ & $\begin{array}{l}\text { A decrease in the number of } \\
\text { vaccine doses administered } \\
\text { in NYC was detected } \\
\text { beginning the week of Mar } \\
8,2020 \text {; numbers declined } \\
\text { further after March } 22 \text { when } \\
\text { New Yorkers were required } \\
\text { to stay at home The largest } \\
\text { relative decrease was } \\
\text { observed Apr } 5-11 \text { and was } \\
\text { less pronounced in <24 } \\
\text { months (62\% decrease, } \\
\text { from } 33,261 \text { doses in } 2019 \\
\text { to } 12,746 \text { doses in } 2020) \\
\text { than in } 2-18 \text { years olds } \\
\text { (96\% decrease, from } 23,631 \\
\text { doses in } 2019 \text { to } 1,054 \\
\text { doses in } 2020) \text {. Vaccine } \\
\text { administration increased } \\
<24 \text { months starting Apr } 19- \\
25, \text { and returned to levels } \\
\text { comparable with } 2019 \text { on } \\
\text { May } 17 . \text { Vaccine } \\
\text { administration among } 2-18- \\
\text { year-olds increased April } \\
26-\text { May } 2 \text { and continued to } \\
\text { rise, but as of June } 27 \text { still }\end{array}$ \\
\hline
\end{tabular}


medRxiv preprint doi: https://doi.org/10.1101/2021.06.25.21259371; this version posted June 30, 2021. The copyright holder for this preprint (which was not certified by peer review) is the author/funder, who has granted medRxiv a license to display the preprint in perpetuity. It is made available under a CC-BY-ND 4.0 International license .

Carl Heneghan, Jon Brassey, and Tom Jefferson

The Impact of COVID-19 Restrictions on Childhood Vaccination Uptake: A Rapid Review

Collateral Global June 2021

\begin{tabular}{|c|c|c|c|c|c|c|}
\hline & & & & & & $\begin{array}{l}\text { had not reached levels } \\
\text { comparable with } 2019 .\end{array}$ \\
\hline $\begin{array}{l}\text { Masresha } \\
\text { BG } 2020\end{array}$ & Africa & General & $\begin{array}{l}\text { Retrospective } \\
\text { cohort }\end{array}$ & $\begin{array}{l}\text { Review of the administrative } \\
\text { routine immunization data } \\
\text { from } 15 \text { African countries for } \\
\text { the period from January } 2018 \\
\text { to June } 2020 \text { and compared } \\
\text { with the first three months of } \\
\text { the COVID-19 pandemic. }\end{array}$ & $\begin{array}{l} \\
\\
\text { Children } \\
\text { receiving } \\
\text { BCG, DPT1 \& } \\
\text { DPT3, MCV1 } \\
\text { and MCV2. }\end{array}$ & $\begin{array}{l}13 / 15 \text { countries showed a } \\
\text { decline in the monthly } \\
\text { average number of vaccine } \\
\text { doses provided, with } 6 \\
\text { countries having more than } \\
10 \% \text { decline. Nine countries } \\
\text { had lower monthly mean } \\
\text { recipients of first dose } \\
\text { measles vaccination in the } \\
\text { second quarter of } 2020 \\
\text { compared to the first } \\
\text { quarter. Guinea, Nigeria, } \\
\text { Ghana, Angola, Gabon, and } \\
\text { South Sudan experienced a } \\
\text { drop in the monthly number } \\
\text { of children vaccinated for } \\
\text { DPT3 and/or MCV1 of } \\
\text { greater than } 2 \text { standard } \\
\text { deviations at some point in } \\
\text { the second quarter of } 2020 \\
\text { as compared to the mean } \\
\text { for the months January- } \\
\text { June of } 2018 \text { and } 2019 .\end{array}$ \\
\hline $\begin{array}{l}\text { McDonald } \\
2020\end{array}$ & England & General & $\begin{array}{l}\text { Retrospective } \\
\text { cohort }\end{array}$ & $\begin{array}{l}\text { Using electronic health } \\
\text { records, we assessed the } \\
\text { early impact of coronavirus } \\
\text { disease (COVID-19) on } \\
\text { routine childhood vaccination } \\
\text { in England by } 26 \text { April } 2020 \text {. }\end{array}$ & $<1$ year & $\begin{array}{l}\text { MMR vaccination counts fell } \\
\text { from Feb } 2020 \text {, and in the } 3 \\
\text { weeks after physical } \\
\text { distancing measures were } \\
19.8 \% \text { lower }(95 \% \mathrm{Cl},-20.7 \\
\text { to }-18.9) \text { than } 2019 \text {, before } \\
\text { improving in mid-April. The } \\
\text { MMR vaccination counts } \\
\text { also followed a similar } \\
\text { pattern in } 2020 \text { until week } \\
11 \text { when they fell and } \\
\text { remained low for several } \\
\text { weeks before rising in week } \\
16 \text {. }\end{array}$ \\
\hline $\begin{array}{l}\text { Middeldorp } \\
\text { M } 2021\end{array}$ & Netherlands & General & $\begin{array}{l}\text { Retrospective } \\
\text { cohort }\end{array}$ & $\begin{array}{l}\text { Data on the monthly number } \\
\text { of cases reported from } \\
\text { January } 2019 \text { through } \\
\text { September } 2020 \text { were } \\
\text { compared with data from the } \\
\text { five preceding years. }\end{array}$ & Children & $\begin{array}{l}\text { The incidence of various } \\
\text { VPDs initially decreased by } \\
75-97 \% \text { after the } \\
\text { implementation of } \\
\text { measures. The participation } \\
\text { in MMR1 vaccination in Mar- } \\
\text { Sep } 2020 \text { initially dropped } \\
\text { by } 6-14 \% \text {. After catch-up, a } \\
\text { difference in MMR1 } \\
\text { participation of }-1 \% \text { to }-2 \% \\
\text { remained. }\end{array}$ \\
\hline $\begin{array}{l}\text { Miretu DG } \\
2021\end{array}$ & Ethiopia & General & Survey & $\begin{array}{l}633 \text { children with their } \\
\text { mother/caregiver were } \\
\text { interviewed from Jul } 22 \text { to } \\
\text { Aug } 7,2020 \text {, in Dessie town, } \\
\text { Ethiopia. The response rate } \\
\text { was } 96.4 \% \text {. }\end{array}$ & $\begin{array}{l}15-23 \\
\text { months }\end{array}$ & $\begin{array}{l}\text { Based on the vaccination } \\
\text { card plus recall, } 350 \\
(57.4 \%) \text { of children finished } \\
\text { all recommended vaccines. } \\
\text { Age-eligible vaccination } \\
\text { coverage during the COVID- } \\
19 \text { outbreak was } 12.5 \% \\
\text { lower than before the } \\
\text { outbreak. }\end{array}$ \\
\hline
\end{tabular}


medRxiv preprint doi: https://doi.org/10.1101/2021.06.25.21259371; this version posted June 30, 2021. The copyright holder for this preprint (which was not certified by peer review) is the author/funder, who has granted medRxiv a license to display the preprint in perpetuity. It is made available under a CC-BY-ND 4.0 International license .

Carl Heneghan, Jon Brassey, and Tom Jefferson

The Impact of COVID-19 Restrictions on Childhood Vaccination Uptake: A Rapid Review

Collateral Global June 2021

\begin{tabular}{|c|c|c|c|c|c|c|}
\hline $\begin{array}{l}\text { Moraga- } \\
\text { Llop FA } \\
2020\end{array}$ & Spain & General & Survey & $\begin{array}{l}\text { Review of data from } \\
\text { Autonomous Communities } \\
\text { depending on the age and } \\
\text { type of vaccine }\end{array}$ & Children & $\begin{array}{l}\text { Despite health authority } \\
\text { recommendations } \\
\text { vaccination coverage } \\
\text { decreased in all } \\
\text { Autonomous Communities } \\
\text { between } 5 \% \text { and } 60 \% \text {, } \\
\text { depending on the age and } \\
\text { type of vaccine. School } \\
\text { vaccinations were } \\
\text { suspended and only } \\
\text { vaccination of pregnant } \\
\text { women against tetanus, } \\
\text { diphtheria and pertussis was } \\
\text { maintained. The first dose of } \\
\text { meningococcal vaccine B } \\
\text { has decreased by } 68.4 \% \text { in } \\
\text { the Valencian Community, } \\
\text { and Andalusia has observed } \\
\text { a } 39 \% \text { decrease in the total } \\
\text { doses of this vaccine and of } \\
18 \% \text { for that of rotavirus. }\end{array}$ \\
\hline $\begin{array}{l}\text { Poppe M } \\
2021\end{array}$ & Portugal & General & Survey & $\begin{array}{l}\text { An anonymous online survey } \\
\text { via social media. Data was } \\
\text { collected between the } 16 \text { th of } \\
\text { March and the } 17 \text { th of May } \\
2020 \text {. }\end{array}$ & Children & $\begin{array}{l}\text { Responses for } 19745 \\
\text { children were obtained and } \\
21.6 \% \text { of planned } \\
\text { vaccinations were missed. } \\
\text { Parents expressed concerns } \\
\text { regarding psychological, } \\
\text { social, and physical } \\
\text { consequences for their } \\
\text { children due to the } \\
\text { pandemic }\end{array}$ \\
\hline $\begin{array}{l}\text { Rana S } \\
2021\end{array}$ & Bangladesh & General & $\begin{array}{l}\text { Retrospective } \\
\text { cohort with } \\
\text { historical } \\
\text { controls }\end{array}$ & $\begin{array}{l}\text { Retrieved annual data for } \\
2019 \text { and } 2020 \text { from } \\
\text { Bangladesh's district health } \\
\text { information system (DHIS) for } \\
\text { child immunisation and sick } \\
\text { children's care-seeking in six } \\
\text { subdistricts of Barishal, } \\
\text { Bangladesh. }\end{array}$ & $<5$ years & $\begin{array}{l}\text { Child immunisation services } \\
\text { were mostly disrupted in } \\
\text { April and May } 2020 \text {, when } \\
20 \% \text { ( } 280 \text { of } 1414 \text { ) and } 25 \% \\
\text { ( } 346 \text { of } 1395 \text { ) of planned } \\
\text { outreach immunisation } \\
\text { sessions were cancelled, } \\
\text { respectively. On average, } \\
\text { the greatest disruption was } \\
\text { observed during these } \\
\text { months in three remote } \\
\text { subdistricts: Hijla (57\% [185 } \\
\text { of } 322]), \text { Agailjhara ( } 25 \% \text { [69 } \\
\text { of } 275]), \text { and Mehendiganj } \\
\text { (20\% [135 of } 660]) \text {. }\end{array}$ \\
\hline $\begin{array}{l}\text { Russo R } \\
2021\end{array}$ & Italy & General & Survey & $\begin{array}{l}\text { A survey among Italian } \\
\text { families on children } \\
\text { vaccination during lockdown } \\
\text { period. }\end{array}$ & Children & $\begin{array}{l}\text { Out of } 1474 \text { responders, } \\
34 \% \text { skipped the vaccine } \\
\text { appointment as they were } \\
\text { afraid of SARS-CoV-2-virus } \\
\text { ( } 44 \%) \text {, vaccination services } \\
\text { postponed the appointment } \\
(42 \%) \text { or were closed }(13 \%) \text {. }\end{array}$ \\
\hline $\begin{array}{l}\text { Santoli JM } \\
2020\end{array}$ & USA & General & $\begin{array}{l}\text { Retrospective } \\
\text { cohort with } \\
\text { historical } \\
\text { controls }\end{array}$ & $\begin{array}{l}\text { Data analyses from CDC's } \\
\text { Vaccine Tracking System and } \\
\text { Vaccine Safety Datalink } \\
\text { (VSD) vaccine administration } \\
\text { data. Cumulative doses of } \\
\text { Vaccines ordered by health } \\
\text { care providers weekly from } \\
\text { Jan } 7,2019-\text { Apr } 21,2019 \\
\text { [period 1] and Jan } 6,2020- \\
\text { Apr 19, 2020 [period 2]) were } \\
\text { compared between two age } \\
\text { groups: aged } \leq 24 \text { months }\end{array}$ & $\begin{array}{l}\leq 24 \text { months \& } \\
\text { aged }>24 \\
\text { months } \\
\text { through } 18 \\
\text { years }\end{array}$ & $\begin{array}{l}\text { A notable decrease in } \\
\text { orders for VFC-funded was } \\
\text { noted, ACIP-recommended } \\
\text { non-influenza childhood } \\
\text { vaccines and for measles- } \\
\text { containing vaccines during } \\
\text { period } 2 \text { compared with } \\
\text { period } 1 . \text { Approx reduction } \\
\text { of } 3 \text { million doses ordered } \\
\text { for non-influenza vaccines } \\
\text { and } 400,000 \text { measles- } \\
\text { containing diseases over } 15 \\
\text { weeks. }\end{array}$ \\
\hline
\end{tabular}


medRxiv preprint doi: https://doi.org/10.1101/2021.06.25.21259371; this version posted June 30, 2021. The copyright holder for this preprint (which was not certified by peer review) is the author/funder, who has granted medRxiv a license to display the preprint in perpetuity. It is made available under a CC-BY-ND 4.0 International license .

Carl Heneghan, Jon Brassey, and Tom Jefferson

The Impact of COVID-19 Restrictions on Childhood Vaccination Uptake: A Rapid Review

Collateral Global June 2021

\begin{tabular}{|c|c|c|c|c|c|c|}
\hline & & & & $\begin{array}{l}\text { and }>24 \text { months through } 18 \\
\text { years. }\end{array}$ & & \\
\hline $\begin{array}{l}\text { Schmid- } \\
\text { Küpke NK } \\
2021\end{array}$ & Germany & General & Survey & $\begin{array}{l}\text { Data within three waves } \\
\text { (waves } 7,9 \text {, and 14) of } \\
\text { COSMO, a serial cross- } \\
\text { sectional survey monitoring } \\
\text { public perceptions of risk, } \\
\text { trust, knowledge, and } \\
\text { misinformation on COVID-19 } \\
\text { measures. Since Mar 3, } \\
2020 \text {, about } 1000 \text { participants } \\
\text { weekly (since June, } \\
\text { fortnightly) }\end{array}$ & Children & $\begin{array}{l}\text { The } 1 \text { st data collection (14th } \\
\text { April) indicated that } 73 / 306 \\
\text { children had vaccination } \\
\text { appointments in the last six } \\
\text { weeks, and } 31 / 73(43 \%) \\
\text { were cancelled. Nearly all } \\
\text { because of the pandemic } \\
26 / 31(84 \%) \text {. Half indicated } \\
\text { their paediatrician cancelled } \\
\text { the appointment }(12 / 26= \\
46 \%) \text {, The remaining by the } \\
\text { patients themselves }(14 / 26 \\
=53.9 \%) \text {. In June } 48 / 82= \\
59 \% \text { vaccinations in children } \\
\text { took place. }\end{array}$ \\
\hline $\begin{array}{l}\text { Seither R } \\
2021\end{array}$ & USA & General & $\begin{array}{l}\text { Retrospective } \\
\text { cohort }\end{array}$ & $\begin{array}{l}\text { Retrospective data collected } \\
\text { by state and local } \\
\text { immunization programs* } \\
\text { vaccination coverage among } \\
\text { children in kindergarten in } 48 \\
\text { US states, exemptions for } \\
\text { kindergartners in } 49 \text { states, } \\
\text { and provisional enrollment } \\
\text { and grace period status for } \\
\text { kindergartners in } 28 \text { states for } \\
\text { the 2019-20 school year. }\end{array}$ & $\begin{array}{l}\text { First-year of } \\
\text { primary } \\
\text { education in } \\
\text { the US (5-6 } \\
\text { years) }\end{array}$ & $\begin{array}{l}\text { Vaccination coverage was } \\
94.9 \% \text { for the state-required } \\
\text { number of doses of } \\
\text { diphtheria and tetanus, and } \\
\text { acellular pertussis vaccine } \\
\text { (DTaP); } 95.2 \% \text { for } 2 \text { doses } \\
\text { of measles, mumps, and } \\
\text { rubella vaccine (MMR); and } \\
94.8 \% \text { for the state-required } \\
\text { number of varicella vaccine } \\
\text { doses. ( } 2.5 \% \text { of } \\
\text { kindergartners had an } \\
\text { exemption from at least one } \\
\text { vaccine; } 2.3 \% \text { were not up } \\
\text { to date for MMR and did not } \\
\text { have a vaccine exemption). }\end{array}$ \\
\hline $\begin{array}{l}\text { Shet A } \\
2021\end{array}$ & India & General & Survey & $\begin{array}{l}\text { Surveyed paediatric } \\
\text { healthcare providers in India } \\
\text { in } 2 \text { rounds in April-June and } \\
\text { September } 2020 \text { to } \\
\text { understand how COVID- } 19 \\
\text { control measures may have } \\
\text { impacted routine vaccination. }\end{array}$ & Children & $\begin{array}{l}\text { Among the } 424 \text { (survey } 1 \text { ) } \\
\text { and } 141 \text { (survey } 2 \text { ) } \\
\text { respondents, } 33.4 \% \text { and } \\
7.8 \% \text {, respectively, reported } \\
\text { near complete suspension } \\
\text { of vaccination services due } \\
\text { to COVID-19. A } 50 \% \text { or } \\
\text { greater drop-in vaccination } \\
\text { services was reported by } \\
83 \% \text { of respondents in June, } \\
\text { followed by } 323 \% \text { four } \\
\text { months later. }\end{array}$ \\
\hline $\begin{array}{l}\text { Sow A } \\
2020\end{array}$ & Senegal & General & $\begin{array}{l}\text { Retrospective } \\
\text { cohort with } \\
\text { historical } \\
\text { controls }\end{array}$ & $\begin{array}{l}\text { Analysis in the vaccination } \\
\text { unit of the Abass NDAO } \\
\text { hospital centre in Senegal } \\
\text { comparing } 2020 \text { data from } \\
\text { Mar to Aug to the last three } \\
\text { years of vaccine administered } \\
\text { at birth (BCG, poliomyelitis), } \\
\text { at } 6 \text { weeks at } 10 \text { weeks } \\
\text { (pentavalent, pneumococcal, } \\
\text { rotavirus and polio vaccine), } \\
\text { at } 14 \text { weeks and } 9 \text { months } \\
\text { (measles, rubella and yellow } \\
\text { fever). }\end{array}$ & $\begin{array}{l}6 \text { weeks to } 9 \\
\text { months }\end{array}$ & $\begin{array}{l}\text { For the vaccines } \\
\text { administered in the sixth } \\
\text { week in April, the number of } \\
\text { doses was } 36 \text { in } 2018,29 \text { in } \\
2019 \text { and } 15 \text { in } 2020 \text {, a } \\
\text { decrease of } 50 \% \text { compared } \\
\text { to March. In July, the } \\
\text { number of doses } \\
\text { administered was } 40 \text { in } \\
2018 \text {, } 35 \text { in } 2019 \text { and } 15 \text { in } \\
2020 \text {, i.e. a reduction of } \\
42 \% \text { compared to } 2019 \text {. }\end{array}$ \\
\hline
\end{tabular}


medRxiv preprint doi: https://doi.org/10.1101/2021.06.25.21259371; this version posted June 30, 2021. The copyright holder for this preprint (which was not certified by peer review) is the author/funder, who has granted medRxiv a license to display the preprint in perpetuity. It is made available under a CC-BY-ND 4.0 International license .

Carl Heneghan, Jon Brassey, and Tom Jefferson

The Impact of COVID-19 Restrictions on Childhood Vaccination Uptake: A Rapid Review

Collateral Global June 2021

\begin{tabular}{|c|c|c|c|c|c|c|}
\hline $\begin{array}{l}\text { Vogt TM } \\
2020\end{array}$ & USA & General & Survey & $\begin{array}{l}\text { A May } 2020 \text { survey of } 1,933 \\
\text { practices participating in the } \\
\text { Vaccines for Children } \\
\text { program }\end{array}$ & Children & $\begin{array}{l}1,727(89.8 \%) \text { of } 1,993 \\
\text { practices were currently } \\
\text { open, including } 1,397 \text { ( } 81 \%) \\
\text { offering immunization } \\
\text { services to all paediatric } \\
\text { patients. Among responding } \\
\text { practices, } 1,135(59 \%) \text { were } \\
\text { likely able to provide } \\
\text { immunization services to } \\
\text { new paediatric patients if } \\
\text { necessary. }\end{array}$ \\
\hline $\begin{array}{l}\text { Wale TA } \\
2020\end{array}$ & Ethiopia & General & $\begin{array}{l}\text { Mixed } \\
\text { methods } \\
\text { survey and } \\
\text { interviews }\end{array}$ & $\begin{array}{l}\text { Community-based mixed } \\
\text { quantitative and qualitative } \\
\text { cross-sectional study in } \\
\text { southwest Ethiopia. Data was } \\
\text { collected using semi- } \\
\text { structured questionnaires and } \\
\text { in-depth interviews. }\end{array}$ & $\begin{array}{c}\text { Children aged } \\
10-23 \\
\text { months }\end{array}$ & $\begin{array}{l}\text { Of the total respondents, } \\
1,110(85 \%) \text { took both BCG } \\
\text { and OPV vaccine, from } \\
1,110 \text { BCG started children } \\
\text { only } 798(71.8 \%) \text { completed } \\
\text { their immunization. Of } 1,300 \\
\text { children, } 190 \text { ( } 14.6 \%) \text { were } \\
\text { not taking any vaccine at all. } \\
\text { Overall } 1,088(84 \%) \\
\text { received both PCV one and } \\
\text { Penta one, } 1082(83 \%) \\
\text { received rota1 and } 798 \\
(61 \%) \text { received measles } \\
\text { vaccine. The coverage rate } \\
\text { declined for the consecutive } \\
\text { dose, such as OPV zero } \\
(85.4 \%) \text { to OPV three } \\
\text { (73.7\%), both Penta and } \\
\text { PCV one (83.7\%) to Penta } \\
\text { and PCV three }(71.9 \%) \text {. The } \\
\text { percentage of incomplete } \\
\text { immunization among } \\
\text { children aged from } 10 \text { to } 23 \\
\text { months was found to be } 809 \\
\text { (62.2\%, } 95 \% \text { Cl: } 59.5,64.8) \text {. }\end{array}$ \\
\hline $\begin{array}{l}\text { Wanyana } \\
\text { D } 2021\end{array}$ & Rwanda & General & $\begin{array}{l}\text { Retrospective } \\
\text { cohort with } \\
\text { historical } \\
\text { controls }\end{array}$ & $\begin{array}{l}\text { Analyzed data from the } \\
\text { Rwanda Health Management } \\
\text { Information System (HMIS) } \\
\text { estimated } 2020 \text { population: } \\
\text { 12,663,117. Analysis from } \\
\text { Mar and Apr } 2019 \text { (before the } \\
\text { COVID-19 outbreak) were } \\
\text { compared with Mar and Apr } \\
\text { 2020. }\end{array}$ & $\begin{array}{c}12-23 \\
\text { months }\end{array}$ & $\begin{array}{l}\text { Vaccinations: bacille } \\
\text { Calmette-Guérin (BCG) } \\
\text { from } 1.06 \text { in } 2019 \text { to } 0.95 \text { in } \\
2020(P=0.002) \text {, polio zero } \\
\text { from } 0.97 \text { to } 0.86 \text { ( } P= \\
0.001), \text { polio } 1 \text { from } 0.97 \text { to } \\
0.89 \text { ( } P=0.008) \text {, polio } 2 \\
\text { from } 0.95 \text { to } 0.88 \text { ( } P= \\
0.008) \text {, diphtheria, tetanus, } \\
\text { pertussis, hepatitis } B \text { and } \\
\text { haemophilus influenzae } \\
\text { (DTP_HepB_Hib) } 1 \text { from } \\
0.97 \text { to } 0.89(P=0.007), \\
D T P \text { HepB_Hib } 2 \text { from } 0.95 \\
\text { to } 0.88(P=0.007), \\
\text { pneumococcus } 1 \text { from } 0.97 \\
\text { to } 0.89(P=0.007), \\
\text { pneumococcus } 2 \text { from } 0.95 \\
\text { to } 0.88(P=0.007), \\
\text { rotavirus } 1 \text { from } 0.98 \text { to } 0.89 \\
(P=0.006) \text { and rotavirus } 2 \\
\text { from } 0.95 \text { to } 0.88 \text { ( } P= \\
0.009) \text {. }\end{array}$ \\
\hline $\begin{array}{l}\text { Yu JH } \\
2021\end{array}$ & $\begin{array}{l}\text { South } \\
\text { Korea }\end{array}$ & General & $\begin{array}{l}\text { Retrospective } \\
\text { cohort with } \\
\text { historical } \\
\text { controls }\end{array}$ & $\begin{array}{l}\text { National vaccination } \\
\text { coverage of } 10 \text { essential } \\
\text { children vaccines between } \\
\text { Jan-June } 2019 \text { and } 2020 \text {. } \\
\text { Coverage was based on the } \\
\text { resident population data of } \\
\text { the Korean Ministry of Public }\end{array}$ & $<6$ years & $\begin{array}{l}\text { During the COVID- } 19 \\
\text { outbreak, the vaccination } \\
\text { rate in children aged } 0 \text { to } 35 \\
\text { months in Korea did not } \\
\text { decrease significantly, } \\
\text { whereas the vaccination } \\
\text { rate for children aged } 4 \text { to } 6\end{array}$ \\
\hline
\end{tabular}


medRxiv preprint doi: https://doi.org/10.1101/2021.06.25.21259371; this version posted June 30, 2021. The copyright holder for this preprint (which was not certified by peer review) is the author/funder, who has granted medRxiv a license to display the preprint in perpetuity. It is made available under a CC-BY-ND 4.0 International license .

Carl Heneghan, Jon Brassey, and Tom Jefferson

The Impact of COVID-19 Restrictions on Childhood Vaccination Uptake: A Rapid Review

Collateral Global June 2021

\begin{tabular}{|c|c|c|c|c|c|c|}
\hline & & & & $\begin{array}{l}\text { Administration and Security, } \\
\text { which covers } 100 \% \text { of } \\
\text { national immunization in the } \\
\text { country. }\end{array}$ & & $\begin{array}{l}\text { decreased by } 1.4-1.9 \% \text {. } \\
\text { The overall incidence of } \\
\text { VPDs decreased by } 10- \\
50 \% \text { between } 2019 \text { and } \\
2020 \text {, especially varicella. }\end{array}$ \\
\hline $\begin{array}{l}\text { Kitano T } \\
2021\end{array}$ & Japan & $\begin{array}{c}\text { Haemophilus } \\
\text { influenza } \\
\text { type b }\end{array}$ & $\begin{array}{l}\text { Model and } \\
\text { Retrospective } \\
\text { cohort with } \\
\text { historical } \\
\text { controls }\end{array}$ & $\begin{array}{l}\text { Incidences of invasive Hib } \\
\text { disease among 0-4-year-olds } \\
\text { in the pre-vaccine (2008- } \\
2010) \text { and post-vaccine } \\
\text { period (2013-2019) before } \\
\text { the COVID-19 outbreak were } \\
\text { compared }\end{array}$ & $<5$ years & $\begin{array}{l}\text { The national Hib vaccination } \\
\text { rate after the impact of } \\
\text { COVID-19 reduced to } 87 \% \\
\text { and } 73 \% \text { in } 2020 \text { from } \\
\text { approximately } 97 \% \text { each in } \\
2013-2019 \text { for primary and } \\
\text { booster doses. }\end{array}$ \\
\hline $\begin{array}{l}\text { AlHajri B } \\
2021\end{array}$ & Kuwait & Influenza & Survey & $\begin{array}{l}\text { online survey to adults in } \\
\text { Kuwait between Aug } 26 \text { and } \\
\text { Sep } 12020 \text { ( } n=2368 ; 1038 \\
\text { participants with children } \\
\text { aged <18 years). }\end{array}$ & $<18$ years & $\begin{array}{l}17.6 \% \text { of parents }(183 / 1038) \\
\text { reported their children } \\
\text { received the influenza } \\
\text { vaccine in the last season. } \\
\text { Of the participating parents, } \\
33 \%(342 / 1038) \text { indicated } \\
\text { they definitely/probably will } \\
\text { vaccinate their children in } \\
\text { the coming influenza } \\
\text { season. }\end{array}$ \\
\hline $\begin{array}{l}\text { Carias C } \\
2021\end{array}$ & USA & Measles & Modelling & $\begin{array}{l}\text { Projected measles } \\
\text { vaccination coverage for one- } \\
\text { year-olds in } 2020 \text { in the US, } \\
\text { for different durations of stay- } \\
\text { at-home orders,. }\end{array}$ & $\begin{array}{l}\text { Infants born } \\
\text { in } 2019 \text { aged } \\
12 \text { months }\end{array}$ & $\begin{array}{l}\text { For a two-month } 2020 \text { stay- } \\
\text { at-home order with a } \\
\text { reduction in measles- } \\
\text { containing vaccine } \\
\text { administration by } 50 \% \\
\text { (base-case), estimated a } \\
\text { decline in vaccination } \\
\text { coverage for infants born in } \\
2019 \text { from } 90 \% \text { to } 82 \% \text { for } \\
\text { the first dose of the } \\
\text { measles-containing vaccine } \\
\text { with no catch-up. In } \\
\text { scenarios with catch-up } \\
\text { vaccination after stay-at- } \\
\text { home orders are lifted, the } \\
\text { projected coverage would } \\
\text { increase to } 90 \% \text { with a } 15 \% \\
\text { increase in the number of } \\
\text { well-child visits over } \\
\text { baseline for the rest of the } \\
\text { year. }\end{array}$ \\
\hline $\begin{array}{l}\text { Ahmadi A } \\
2020\end{array}$ & Afghanistan & Polio & $\begin{array}{l}\text { Retrospective } \\
\text { cohort }\end{array}$ & $\begin{array}{l}\text { Review of WHO GPEI polio } \\
\text { data and Afghanistan policies } \\
\text { (data is up to August 2020); } \\
\text { however, there is now data till } \\
\text { March } 2021\end{array}$ & Children & $\begin{array}{l}\text { National immunization days } \\
\text { aim to cover around } 10 \\
\text { million children against } \\
\text { polio. However, in } 2020, \\
\text { only two programs were } \\
\text { conducted before the } \\
\text { outbreak of COVID-19 in the } \\
\text { country. Vaccine stocks ran } \\
\text { precariously low as supply } \\
\text { chains were disrupted by } \\
\text { travel bans. Many health } \\
\text { facilities where children } \\
\text { were normally vaccinated } \\
\text { were closed. Polio cases } \\
\text { have recently emerged in } \\
\text { three provinces, Balkh, } \\
\text { Herat, and Badakhshan, } \\
\text { which had not reported any } \\
\text { cases in the past } 5 \text { years. } \\
\text { On May } 21,2020 \text {, the } \\
\text { government of Afghanistan } \\
\text { ratified an initial plan for }\end{array}$ \\
\hline
\end{tabular}


medRxiv preprint doi: https://doi.org/10.1101/2021.06.25.21259371; this version posted June 30, 2021. The copyright holder for this preprint (which was not certified by peer review) is the author/funder, who has granted medRxiv a license to display the preprint in perpetuity. It is made available under a CC-BY-ND 4.0 International license.

Carl Heneghan, Jon Brassey, and Tom Jefferson

The Impact of COVID-19 Restrictions on Childhood Vaccination Uptake: A Rapid Review

Collateral Global June 2021

\begin{tabular}{|c|c|c|c|c|c|c|}
\hline & & & & & & $\begin{array}{l}\text { loosening restrictions and } \\
\text { allowing some businesses, } \\
\text { including money exchange } \\
\text { markets and shops, to } \\
\text { reopen. However, this plan } \\
\text { did not include restarting } \\
\text { nationwide polio } \\
\text { vaccination, and as of } \\
\text { August } 1,2020 \text {, the program } \\
\text { remains suspended. }\end{array}$ \\
\hline Din M 2020 & Pakistan & Polio & $\begin{array}{l}\text { Retrospective } \\
\text { cohort }\end{array}$ & $\begin{array}{l}\text { Surveillance for acute flaccid } \\
\text { paralysis (AFP) done for } \\
\text { primary detection of cVDPV } \\
\text { and WPV transmission. } \\
\text { Within the Global Polio } \\
\text { Laboratory Network, stool } \\
\text { specimen testing is done in } \\
\text { WHO-accredited laboratories } \\
\text { for confirmation }\end{array}$ & $<15$ years & $\begin{array}{l}\text { In } 2020 \text {, up to September } 73 \\
\text { cases of Wild Polio Virus } \\
\text { were reported in Pakistan. } \\
\text { and } 62 \text { cases of circulating } \\
\text { vaccine-derived poliovirus } \\
\text { (cVDPV2) have been } \\
\text { detected. }\end{array}$ \\
\hline
\end{tabular}


medRxiv preprint doi: https://doi.org/10.1101/2021.06.25.21259371; this version posted June 30, 2021. The copyright holder for this preprint (which was not certified by peer review) is the author/funder, who has granted medRxiv a license to display the preprint in perpetuity. It is made available under a CC-BY-ND 4.0 International license .

\section{TABLE 2: Reports by National and International Agencies on Childhood Vaccination Uptake During the COVID-19 Pandemic}

\begin{tabular}{|c|c|c|c|}
\hline $\begin{array}{l}\text { Organization } \\
\text { and Year of } \\
\text { Publication }\end{array}$ & Title & Summary & Link \\
\hline $\begin{array}{l}\text { Blue Cross } \\
2020\end{array}$ & $\begin{array}{l}\text { Blue Cross Blue Shield. } \\
\text { Missing vaccinations } \\
\text { during COVID-19 puts } \\
\text { our children and } \\
\text { communities at risk }\end{array}$ & $\begin{array}{l}\text { Reports up to } 26 \% \text { drop in MMR, } \\
\text { DTP \& polio vaccines between } \\
\text { Jan-Sept } 2020 \text { in America. }\end{array}$ & $\begin{array}{l}\text { https://www.bcbs.com/the-health-of- } \\
\text { america/infographics/missing-vaccinations-during- } \\
\text { covid-19-puts-our-children-and-communities-at-risk }\end{array}$ \\
\hline $\begin{array}{l}\text { Nuffield Trust } \\
2021\end{array}$ & $\begin{array}{l}\text { Vaccination coverage } \\
\text { for children and } \\
\text { mothers }\end{array}$ & $\begin{array}{l}\text { Indicators that look at } \\
\text { vaccination coverage for children } \\
\text { and mothers in the UK and } \\
\text { internationally during the } \\
\text { coronavirus (Covid-19) } \\
\text { pandemic, coverage was largely } \\
\text { maintained when compared to } \\
\text { coverage in 2019/20. }\end{array}$ & $\begin{array}{l}\text { https://www.nuffieldtrust.org.uk/resource/vaccination- } \\
\text { coverage-for-children-and-mothers-1 }\end{array}$ \\
\hline $\begin{array}{l}\text { Public Health } \\
\text { England } 2021\end{array}$ & $\begin{array}{l}\text { Impact of COVID-19 on } \\
\text { childhood vaccination } \\
\text { counts to week } 4 \text { in } \\
2021 \text {, and vaccine } \\
\text { coverage to December } \\
2020 \text { in England: } \\
\text { interim analyses }\end{array}$ & $\begin{array}{l}\text { Hexavalent and MMR } \\
\text { vaccination counts fell at the } \\
\text { time of the introduction of } \\
\text { physical distancing measures in } \\
\text { March } 2020 \text { (week 13) compared } \\
\text { to the same period in } 2019 \text {. This } \\
\text { was followed by a rise from } \\
\text { weeks } 16 \text { onwards which has } \\
\text { stabilised and is comparable to } \\
\text { vaccination counts prior to the } \\
\text { COVID-19 pandemic. }\end{array}$ & $\frac{\text { Impact of COVID-19 on childhood vaccination counts to }}{\frac{\text { week 4 in 2021, and vaccine coverage to December }}{2020 \text { in England: interim analyses }}}$ \\
\hline UNICEF 2020 & $\begin{array}{l}\text { Challenges posed by } \\
\text { the COVID-19 } \\
\text { pandemic in the health } \\
\text { of women, children, and } \\
\text { adolescents in Latin } \\
\text { America and the } \\
\text { Caribbean }\end{array}$ & $\begin{array}{l}\text { During the pandemic, the } \\
\text { population's fear of COVID-19 } \\
\text { and public transport limitations } \\
\text { and confinement and physical } \\
\text { distance policies led to a } \\
\text { decrease in the demand for }\end{array}$ & $\begin{array}{l}\text { https://www.unicef.org/lac/media/16376/file/undp-rblac- } \\
\text { CD19-PDS-Number19-UNICEF-Salud-EN.pdf }\end{array}$ \\
\hline PAHO* 2020 & $\begin{array}{l}\text { Summary of the Status } \\
\text { of National } \\
\text { Immunization Programs } \\
\text { during the COVID-19 } \\
\text { Pandemic, July } 2020 .\end{array}$ & $\begin{array}{l}38 \text { countries in the region that } \\
\text { report information to the Pan } \\
\text { American Health Organization } \\
\text { (PAHO). }\end{array}$ & https://iris.paho.org/handle/10665.2/52544 \\
\hline UNICEF 2020 & $\begin{array}{l}\text { Immunization coverage } \\
\text { Are we losing ground? }\end{array}$ & $\begin{array}{l}\text { Lockdown measures had } \\
\text { substantially hindered the } \\
\text { delivery of immunization services } \\
\text { in at least } 68 \text { countries, putting } \\
\text { approximately } 80 \text { million children } \\
\text { under the age of } 1 \text { at increased } \\
\text { risk of contracting vaccine- } \\
\text { preventable diseases. }\end{array}$ & $\begin{array}{l}\text { https://data.unicef.org/resources/immunization- } \\
\text { coverage-are-we-losing-ground/ }\end{array}$ \\
\hline $\begin{array}{l}\text { WHO pulse } \\
\text { interim survey } \\
2020\end{array}$ & $\begin{array}{l}\text { Pulse survey on } \\
\text { continuity of essential } \\
\text { health services during } \\
\text { the COVID-19 } \\
\text { pandemic: interim } \\
\text { report, } 27 \text { August } 2020\end{array}$ & $\begin{array}{l}105 \text { countries responded. } \\
\text { Severe/complete disruption of } \\
\text { outreach routine mobile } \\
\text { immunization services occurred } \\
\text { in } 18 \% \text { of } 91 \text { countries and in } \\
10 \% \text { disruption to static routine } \\
\text { immunization occurred. }\end{array}$ & $\begin{array}{l}\text { https://www.who.int/publications/i/item/WHO-2019- } \\
\text { nCoV-EHS continuity-survey-2020.1 }\end{array}$ \\
\hline
\end{tabular}


medRxiv preprint doi: https://doi.org/10.1101/2021.06.25.21259371; this version posted June 30, 2021. The copyright holder for this preprint (which was not certified by peer review) is the author/funder, who has granted medRxiv a license to display the preprint in perpetuity. It is made available under a CC-BY-ND 4.0 International license .

Carl Heneghan, Jon Brassey, and Tom Jefferson

The Impact of COVID-19 Restrictions on Childhood Vaccination Uptake: A Rapid Review

Collateral Global June 2021

\begin{tabular}{|c|c|c|c|}
\hline $\begin{array}{l}\text { WHO pulse } \\
\text { second-round } \\
\text { survey } 2021\end{array}$ & $\begin{array}{l}\text { The second round of } \\
\text { the national pulse } \\
\text { survey on continuity of } \\
\text { essential health } \\
\text { services during the } \\
\text { COVID-19 pandemic }\end{array}$ & $\begin{array}{l}\text { In January-March } 2021 \text { for } 135 \\
\text { countries surveyed more than } \\
\text { one-third were reporting } \\
\text { disruptions to immunization } \\
\text { services. }\end{array}$ & $\begin{array}{l}\text { https://www.who.int/publications/i/item/WHO-2019- } \\
\text { nCoV-EHS-continuity-survey-2021.1 }\end{array}$ \\
\hline $\begin{array}{l}\text { WHO pulse } \\
\text { survey } 15 \\
\text { May report } \\
2020\end{array}$ & $\begin{array}{l}\text { At least } 80 \text { million } \\
\text { children under one at } \\
\text { risk of diseases such as } \\
\text { diphtheria, measles and } \\
\text { polio as COVID-19 } \\
\text { disrupts routine } \\
\text { vaccination efforts, } \\
\text { warn Gavi, WHO and } \\
\text { UNICEF }\end{array}$ & $\begin{array}{l}\text { More than half }(53 \%) \text { of the } 129 \\
\text { countries where data were } \\
\text { available reported moderate-to- } \\
\text { severe disruptions or a total } \\
\text { suspension of vaccination } \\
\text { services during March-April } \\
2020 .\end{array}$ & $\begin{array}{l}\text { https://www.who.int/news/item/22-05-2020-at-least-80- } \\
\text { million-children-under-one-at-risk-of-diseases-such-as- } \\
\text { diphtheria-measles-and-polio-as-covid-19-disrupts- } \\
\text { routine-vaccination-efforts-warn-gavi-who-and-unicef }\end{array}$ \\
\hline $\begin{array}{l}\text { WHO Niger } \\
2020\end{array}$ & $\begin{array}{l}\text { Niger reports a new } \\
\text { polio outbreak. }\end{array}$ & $\begin{array}{l}\text { Niger has reported a new polio } \\
\text { outbreak that has affected two } \\
\text { children in Niamey and Tillaberi } \\
\text { region, }\end{array}$ & $\begin{array}{l}\text { https://www.afro.who.int/news/niger-reports-new-polio- } \\
\text { outbreak. }\end{array}$ \\
\hline
\end{tabular}

* Pan American Health Organization 
medRxiv preprint doi: https://doi.org/10.1101/2021.06.25.21259371; this version posted June 30, 2021. The copyright holder for this preprint (which was not certified by peer review) is the author/funder, who has granted medRxiv a license to display the preprint in perpetuity.

It is made available under a CC-BY-ND 4.0 International license .

Carl Heneghan, Jon Brassey, and Tom Jefferson

The Impact of COVID-19 Restrictions on Childhood Vaccination Uptake: A Rapid Review

Collateral Global June 2021

\section{Figure 1. PRISMA 2020 Flow Diagram}

\section{Figure 1 Identification of Childhood Vaccination studies via databases}

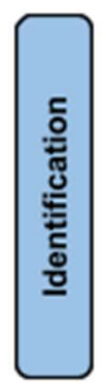

Records identified from

Databases $(n=389)$

Records removed before

screening: $(n=0)$
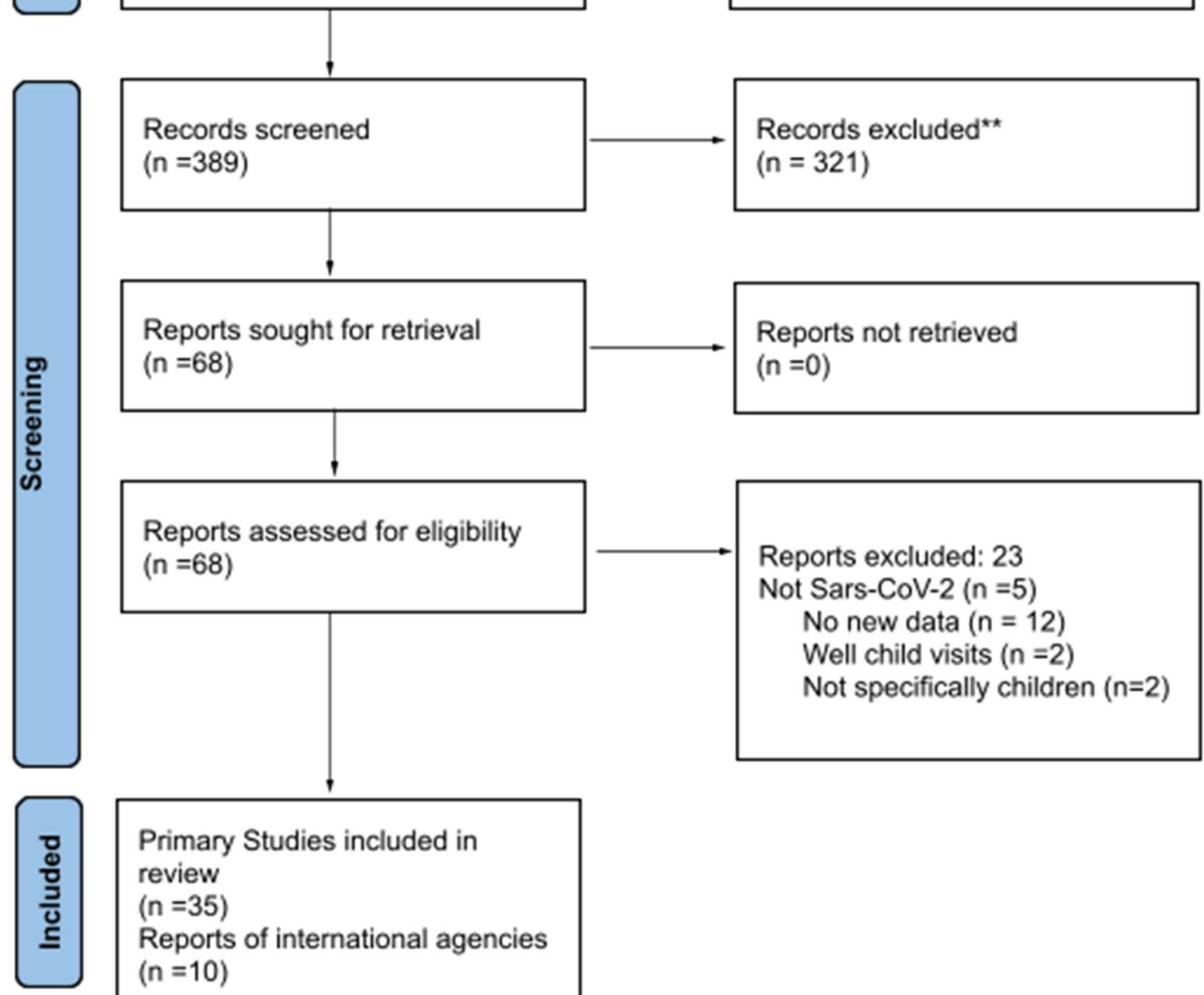

\section{Reports sought for retrieval ( $\mathrm{n}=68$ )}
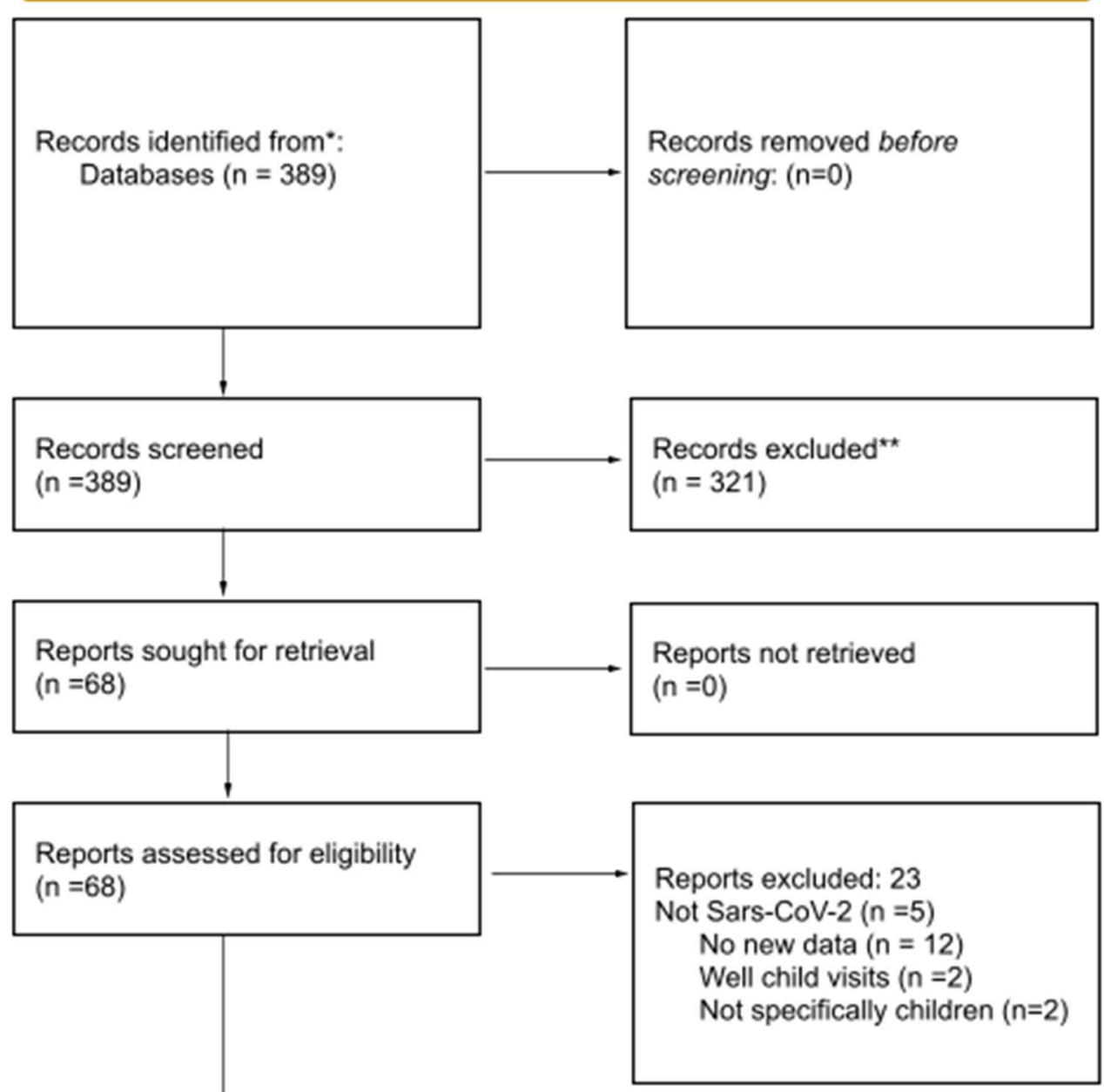

$$
\begin{aligned}
& \text { Primary Studies included in } \\
& \text { review } \\
& (n=35) \\
& \text { Reports of international agencies } \\
& (n=10)
\end{aligned}
$$

${ }^{*}$ Consider, if feasible to do so, reporting the number of records identified from each database or register searched (rather than the total number across all databases/registers).

**If automation tools were used, indicate how many records were excluded by a human and how many were excluded by automation tools.

From: Page MJ, McKenzie JE, Bossuyt PM, Boutron I, Hoffmann TC, Mulrow CD, et al. The PRISMA 2020 statement: an updated guideline for reporting systematic reviews. BMJ 2021;372:n71. doi: 10.1136/bmj.n71 
medRxiv preprint doi: https://doi.org/10.1101/2021.06.25.21259371; this version posted June 30, 2021. The copyright holder for this preprint (which was not certified by peer review) is the author/funder, who has granted medRxiv a license to display the preprint in perpetuity. It is made available under a CC-BY-ND 4.0 International license.

Carl Heneghan, Jon Brassey, and Tom Jefferson

The Impact of COVID-19 Restrictions on Childhood Vaccination Uptake: A Rapid Review

\section{Figure 2. PRISMA Checklist}

\begin{tabular}{|c|c|c|c|}
\hline $\begin{array}{l}\text { Section and } \\
\text { Topic }\end{array}$ & Item \# & Checklist item & $\begin{array}{l}\text { Location } \\
\text { where item } \\
\text { is reported }\end{array}$ \\
\hline \multicolumn{4}{|l|}{ TITLE } \\
\hline Title & 1 & Identify the report as a systematic review. & 1 \\
\hline \multicolumn{4}{|l|}{ ABSTRACT } \\
\hline Abstract & 2 & See the PRISMA 2020 for Abstracts checklist. & 0 \\
\hline \multicolumn{4}{|l|}{ INTRODUCTION } \\
\hline Rationale & 3 & $\begin{array}{l}\text { Describe the rationale for the review in the context of existing } \\
\text { knowledge. }\end{array}$ & 1 \\
\hline Objectives & 4 & $\begin{array}{l}\text { Provide an explicit statement of the objective(s) or question(s) } \\
\text { the review addresses. }\end{array}$ & 1 \\
\hline \multicolumn{4}{|l|}{ METHODS } \\
\hline Eligibility criteria & 5 & $\begin{array}{l}\text { Specify the inclusion and exclusion criteria for the review and } \\
\text { how studies were grouped for the syntheses. }\end{array}$ & 1 \\
\hline $\begin{array}{l}\text { Information } \\
\text { sources }\end{array}$ & 6 & $\begin{array}{l}\text { Specify all databases, registers, websites, organisations, } \\
\text { reference lists and other sources searched or consulted to } \\
\text { identify studies. Specify the date when each source was last } \\
\text { searched or consulted. }\end{array}$ & 1 \\
\hline Search strategy & 7 & $\begin{array}{l}\text { Present the full search strategies for all databases, registers and } \\
\text { websites, including any filters and limits used. }\end{array}$ & 1 \\
\hline Selection process & 8 & $\begin{array}{l}\text { Specify the methods used to decide whether a study met the } \\
\text { inclusion criteria of the review, including how many reviewers } \\
\text { screened each record and each report retrieved, whether they } \\
\text { worked independently, and if applicable, details of automation } \\
\text { tools used in the process. }\end{array}$ & 1 \\
\hline $\begin{array}{l}\text { Data collection } \\
\text { process }\end{array}$ & 9 & $\begin{array}{l}\text { Specify the methods used to collect data from reports, including } \\
\text { how many reviewers collected data from each report, whether } \\
\text { they worked independently, any processes for obtaining or } \\
\text { confirming data from study investigators, and if applicable, } \\
\text { details of automation tools used in the process. }\end{array}$ & 1 \\
\hline \multirow[t]{2}{*}{ Data items } & $10 a$ & $\begin{array}{l}\text { List and define all outcomes for which data were sought. Specify } \\
\text { whether all results that were compatible with each outcome } \\
\text { domain in each study were sought (e.g. for all measures, time } \\
\text { points, analyses), and if not, the methods used to decide which } \\
\text { results to collect. }\end{array}$ & 1 \\
\hline & $10 b$ & $\begin{array}{l}\text { List and define all other variables for which data were sought } \\
\text { (e.g. participant and intervention characteristics, funding } \\
\text { sources). Describe any assumptions made about any missing or } \\
\text { unclear information. }\end{array}$ & 1 \\
\hline $\begin{array}{l}\text { Study risk of bias } \\
\text { assessment }\end{array}$ & 11 & $\begin{array}{l}\text { Specify the methods used to assess risk of bias in the included } \\
\text { studies, including details of the tool(s) used, how many } \\
\text { reviewers assessed each study and whether they worked } \\
\text { independently, and if applicable, details of automation tools } \\
\text { used in the process. }\end{array}$ & 1 \\
\hline Effect measures & 12 & $\begin{array}{l}\text { Specify for each outcome the effect measure(s) (e.g. risk ratio, } \\
\text { mean difference) used in the synthesis or presentation of } \\
\text { results. }\end{array}$ & $N / A$ \\
\hline Synthesis methods & $13 a$ & $\begin{array}{l}\text { Describe the processes used to decide which studies were } \\
\text { eligible for each synthesis (e.g. tabulating the study intervention }\end{array}$ & 1 \\
\hline
\end{tabular}


medRxiv preprint doi: https://doi.org/10.1101/2021.06.25.21259371; this version posted June 30, 2021. The copyright holder for this preprint (which was not certified by peer review) is the author/funder, who has granted medRxiv a license to display the preprint in perpetuity. It is made available under a CC-BY-ND 4.0 International license.

Carl Heneghan, Jon Brassey, and Tom Jefferson

The Impact of COVID-19 Restrictions on Childhood Vaccination Uptake: A Rapid Review

Collateral Global June 2021

\begin{tabular}{|c|c|c|c|}
\hline & & $\begin{array}{l}\text { characteristics and comparing against the planned groups for } \\
\text { each synthesis (item \#5)). }\end{array}$ & \\
\hline & $13 b$ & $\begin{array}{l}\text { Describe any methods required to prepare the data for } \\
\text { presentation or synthesis, such as handling of missing summary } \\
\text { statistics, or data conversions. }\end{array}$ & 1 \\
\hline & $13 c$ & $\begin{array}{l}\text { Describe any methods used to tabulate or visually display } \\
\text { results of individual studies and syntheses. }\end{array}$ & 1 \\
\hline & $13 d$ & $\begin{array}{l}\text { Describe any methods used to synthesize results and provide a } \\
\text { rationale for the choice(s). If meta-analysis was performed, } \\
\text { describe the model(s), method(s) to identify the presence and } \\
\text { extent of statistical heterogeneity, and software package(s) } \\
\text { used. }\end{array}$ & $\mathrm{N} / \mathrm{A}$ \\
\hline & $13 e$ & $\begin{array}{l}\text { Describe any methods used to explore possible causes of } \\
\text { heterogeneity among study results (e.g. subgroup analysis, } \\
\text { meta-regression). }\end{array}$ & $\mathrm{N} / \mathrm{A}$ \\
\hline & $13 f$ & $\begin{array}{l}\text { Describe any sensitivity analyses conducted to assess } \\
\text { robustness of the synthesized results. }\end{array}$ & $\mathrm{N} / \mathrm{A}$ \\
\hline $\begin{array}{l}\text { Reporting bias } \\
\text { assessment }\end{array}$ & 14 & $\begin{array}{l}\text { Describe any methods used to assess risk of bias due to } \\
\text { missing results in a synthesis (arising from reporting biases). }\end{array}$ & $\mathrm{N} / \mathrm{A}$ \\
\hline $\begin{array}{l}\text { Certainty } \\
\text { assessment }\end{array}$ & 15 & $\begin{array}{l}\text { Describe any methods used to assess certainty (or confidence) } \\
\text { in the body of evidence for an outcome. }\end{array}$ & $\mathrm{N} / \mathrm{A}$ \\
\hline \multicolumn{4}{|l|}{ RESULTS } \\
\hline \multirow[t]{2}{*}{ Study selection } & $16 a$ & $\begin{array}{l}\text { Describe the results of the search and selection process, from } \\
\text { the number of records identified in the search to the number of } \\
\text { studies included in the review, ideally using a flow diagram. }\end{array}$ & $1 / 2$ \\
\hline & $16 b$ & $\begin{array}{l}\text { Cite studies that might appear to meet the inclusion criteria, but } \\
\text { which were excluded, and explain why they were excluded. }\end{array}$ & $1 / 2$ \\
\hline $\begin{array}{l}\text { Study } \\
\text { characteristics }\end{array}$ & 17 & Cite each included study and present its characteristics. & $1 / 2$ \\
\hline $\begin{array}{l}\text { Risk of bias in } \\
\text { studies }\end{array}$ & 18 & Present assessments of risk of bias for each included study. & 1 \\
\hline $\begin{array}{l}\text { Results of } \\
\text { individual studies }\end{array}$ & 19 & $\begin{array}{l}\text { For all outcomes, present, for each study: (a) summary statistics } \\
\text { for each group (where appropriate) and (b) an effect estimate } \\
\text { and its precision (e.g. confidence/credible interval), ideally using } \\
\text { structured tables or plots. }\end{array}$ & $2-5$ \\
\hline \multirow[t]{4}{*}{$\begin{array}{l}\text { Results of } \\
\text { syntheses }\end{array}$} & $20 a$ & $\begin{array}{l}\text { For each synthesis, briefly summarise the characteristics and } \\
\text { risk of bias among contributing studies. }\end{array}$ & $\mathrm{N} / \mathrm{A}$ \\
\hline & $20 b$ & $\begin{array}{l}\text { Present results of all statistical syntheses conducted. If meta- } \\
\text { analysis was done, present for each the summary estimate and } \\
\text { its precision (e.g. confidence/credible interval) and measures of } \\
\text { statistical heterogeneity. If comparing groups, describe the } \\
\text { direction of the effect. }\end{array}$ & $2-5$ \\
\hline & $20 c$ & $\begin{array}{l}\text { Present results of all investigations of possible causes of } \\
\text { heterogeneity among study results. }\end{array}$ & $\mathrm{N} / \mathrm{A}$ \\
\hline & $20 d$ & $\begin{array}{l}\text { Present results of all sensitivity analyses conducted to assess } \\
\text { the robustness of the synthesized results. }\end{array}$ & $\mathrm{N} / \mathrm{A}$ \\
\hline Reporting biases & 21 & $\begin{array}{l}\text { Present assessments of risk of bias due to missing results } \\
\text { (arising from reporting biases) for each synthesis assessed. }\end{array}$ & $\mathrm{N} / \mathrm{A}$ \\
\hline $\begin{array}{l}\text { Certainty of } \\
\text { evidence }\end{array}$ & 22 & $\begin{array}{l}\text { Present assessments of certainty (or confidence) in the body of } \\
\text { evidence for each outcome assessed. }\end{array}$ & $2-5$ \\
\hline \multicolumn{3}{|l|}{ DISCUSSION } & \\
\hline
\end{tabular}


medRxiv preprint doi: https://doi.org/10.1101/2021.06.25.21259371; this version posted June 30, 2021. The copyright holder for this preprint (which was not certified by peer review) is the author/funder, who has granted medRxiv a license to display the preprint in perpetuity.

It is made available under a CC-BY-ND 4.0 International license .

Carl Heneghan, Jon Brassey, and Tom Jefferson

The Impact of COVID-19 Restrictions on Childhood Vaccination Uptake: A Rapid Review

Collateral Global June 2021

\begin{tabular}{|l|r|l|l|}
\hline \multirow{2}{*}{ Discussion } & 23a & $\begin{array}{l}\text { Provide a general interpretation of the results in the context of } \\
\text { other evidence. }\end{array}$ & 6 \\
\cline { 2 - 5 } & $23 b$ & Discuss any limitations of the evidence included in the review. & 6 \\
\cline { 2 - 5 } & $23 c$ & Discuss any limitations of the review processes used. & 6 \\
\hline OTHER INFORMATION & $\begin{array}{l}\text { Discuss implications of the results for practice, policy, and future } \\
\text { research. }\end{array}$ & 6 \\
\hline $\begin{array}{l}\text { Registration and } \\
\text { protocol }\end{array}$ & $24 a$ & $\begin{array}{l}\text { Provide registration information for the review, including register } \\
\text { name and registration number, or state that the review was not } \\
\text { registered. }\end{array}$ & N/A \\
\cline { 2 - 5 } & $24 b$ & $\begin{array}{l}\text { Indicate where the review protocol can be accessed, or state } \\
\text { that a protocol was not prepared. }\end{array}$ & 1 \\
\hline \begin{tabular}{l} 
Support \\
\cline { 2 - 5 }
\end{tabular} & $24 c$ & $\begin{array}{l}\text { Describe and explain any amendments to information provided } \\
\text { at registration or in the protocol. }\end{array}$ & 1 \\
\hline $\begin{array}{l}\text { Competing } \\
\text { interests }\end{array}$ & 25 & $\begin{array}{l}\text { Describe sources of financial or non-financial support for the } \\
\text { review, and the role of the funders or sponsors in the review. }\end{array}$ & 7 \\
\hline $\begin{array}{l}\text { Availability of data, } \\
\text { made and other }\end{array}$ & $\begin{array}{l}\text { Declare any competing interests of review authors. } \\
\text { materials }\end{array}$ & $\begin{array}{l}\text { Report which of the following are publicly available and where } \\
\text { they can be found: template data collection forms; data } \\
\text { extracted from included studies; data used for all analyses; } \\
\text { analytic code; any other materials used in the review. }\end{array}$ & 8 \\
\hline
\end{tabular}

From: Page MJ, McKenzie JE, Bossuyt PM, Boutron I, Hoffmann TC, Mulrow CD, et al. The PRISMA 2020 statement: an updated guideline for reporting systematic reviews. BMJ 2021;372:n71. doi: 10.1136/bmj.n71

For more information, visit: http://www.prisma-statement.org/ 